Development Center

Flood and Coastal Systems Research and Development Program

Numerical Hydrodynamic Study of Hypothetical Levee Setback Scenarios

Waleska Echevarria-Doyle and Travis A. Dahl

January 2018

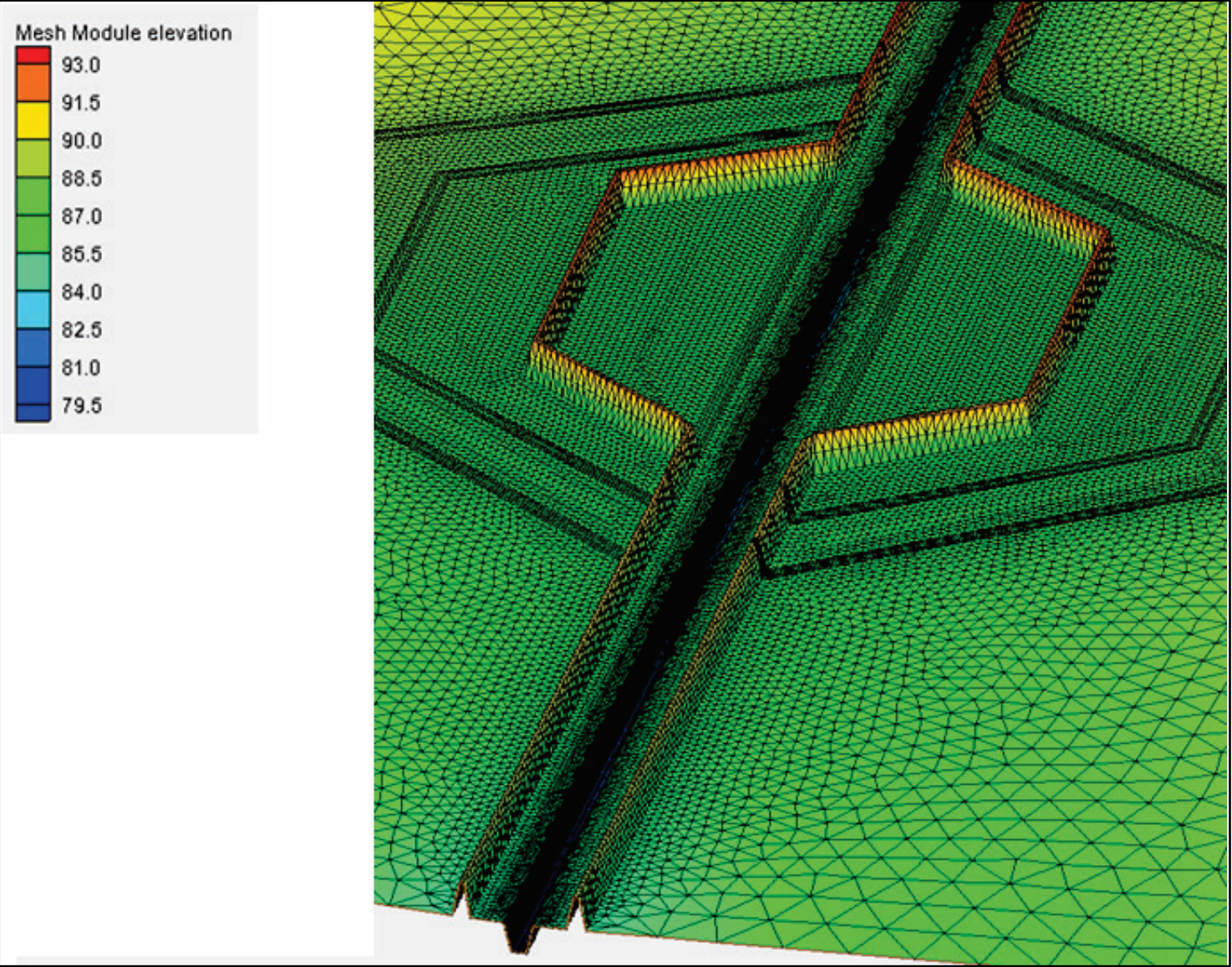


The U.S. Army Engineer Research and Development Center (ERDC) solves the nation's toughest engineering and environmental challenges. ERDC develops innovative solutions in civil and military engineering, geospatial sciences, water resources, and environmental sciences for the Army, the Department of Defense, civilian agencies, and our nation's public good. Find out more at www.erdc.usace.army.mil.

To search for other technical reports published by ERDC, visit the ERDC online library at http://acwc.sdp.sirsi.net/client/default. 


\section{Numerical Hydrodynamic Study of Hypothetical Levee Setback Scenarios}

Waleska Echevarria-Doyle and Travis A. Dahl

Coastal and Hydraulics Laboratory

U.S. Army Engineer Research and Development Center

3909 Halls Ferry Road

Vicksburg, MS 39180-6199

Final report

Approved for public release; distribution is unlimited.

Prepared for U.S. Army Corps of Engineers

Washington, DC 20314-1000

Under Project 454633, “Evaluation of Levee Setbacks and River Restoration Projects for Flood Risk Reduction" 


\section{Abstract}

A numerical hydrodynamic study was conducted to compare multiple levee setback alternatives to the base condition (levee without setbacks). The models developed for this study are hypothetical. An unsteady unit hydrograph representing a flood wave was used to perform the simulations. The levee setback alternatives show a reduction in water surface elevation upstream of and at the setback area when compared with the base condition. The overland water velocity increases upstream of the setback area and decreases at the levee setback area and downstream when compared with the base condition. These hypothetical results indicate that levee setback may be an option to reduce flood risk at a given location; however, exact physical setting and processes, economics, and environmental implications of alternatives must be examined to determine the viability of alternatives. This report provides preliminary information about the effects of levee setbacks on flows and water surface elevations that can be helpful for planners and engineers considering adjusting levee alignment as a flood management alternative.

DISCLAIMER: The contents of this report are not to be used for advertising, publication, or promotional purposes. Citation of trade names does not constitute an official endorsement or approval of the use of such commercial products. All product names and trademarks cited are the property of their respective owners. The findings of this report are not to be construed as an official Department of the Army position unless so designated by other authorized documents. 


\section{Contents}

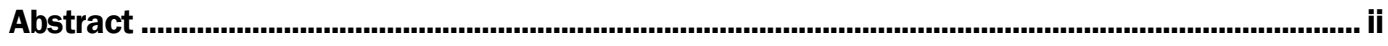

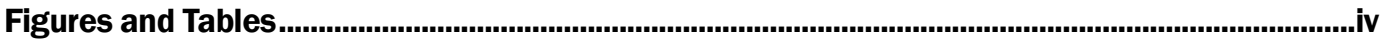

Preface ......................................................................................................................................

Unit Conversion Factors ...............................................................................................................................vii

1 Introduction .................................................................................................................................... 1

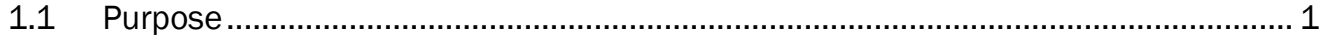

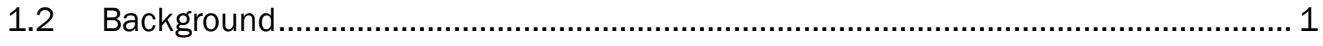

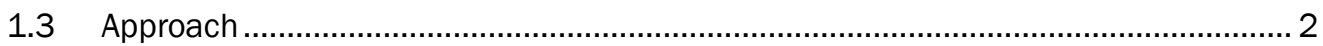

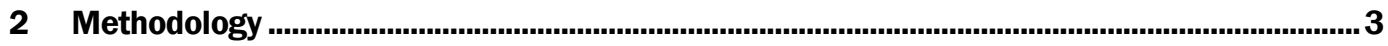

2.1 Geometry of straight channel alternatives........................................................... 3

2.2 Geometry of sinuous channel alternatives ..................................................... 5

2.3 Hydraulic model parameters ...................................................................... 8

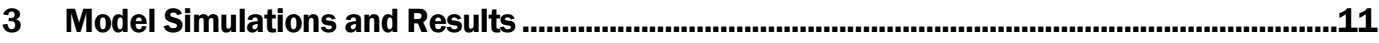

3.1 Straight channel dynamic simulations ............................................................ 11

3.2 Sinuous channel dynamic simulations ......................................................... 17

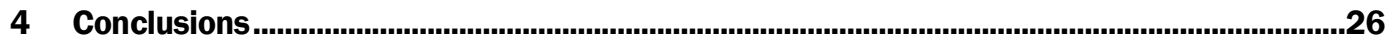

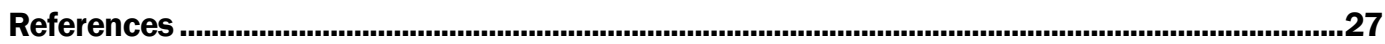

Report Documentation Page 


\section{Figures and Tables}

\section{Figures}

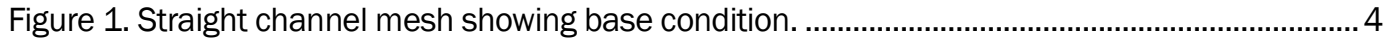

Figure 2. Straight channel mesh showing Alternative 1. ................................................................... 4

Figure 3. Straight channel mesh showing the Alternative 2. .......................................................... 5

Figure 4. Sinuous channel mesh showing the base condition. ............................................................. 6

Figure 5. Sinuous channel mesh showing the Alternative 1...............................................................

Figure 6. Sinuous channel mesh showing the Alternative 2 …….....................................................

Figure 7. Sinuous channel mesh showing the Alternative 3. ............................................................ 8

Figure 8. Synthetic unit hydrograph used in the dynamic simulations.............................................

Figure 9. Savannah River annual peak flows at USGS gage near Augusta, GA. (Source:

USGS Water Resources) ........................................................................................................

Figure 10. Levee setback alternatives and WSE observation points for the straight channel models. Only the central portion of the model domain is shown..........................................11

Figure 11. WSE at the observation point upstream of the levee setback alternatives. ......................12

Figure 12. WSE at the observation point at the levee setback location...............................................13

Figure 13. WSE at the observation point downstream of the levee setback alternatives.................13

Figure 14. Maximum WSE at the setback observation point............................................................14

Figure 15. Overland velocity (meters/second) of the base condition model during the peak discharge.

Figure 16. OV (meters/second) of the levee setback Alternative 1 during the peak discharge.

Figure 17. OV (meters/second) of the levee setback Alternative 2 during the peak discharge.

Figure 18. WSE observation points and levee setback Alternatives 1 and 2 for the sinuous channel. Only the central portion of the model domain is shown.

Figure 19. WSE observation points and levee setback Alternative 3 for the sinuous channel. Only the central portion of the model domain is shown......................................................18

Figure 20. WSE at observation point upstream of the levee setback Alternatives 1 and 2.............19

Figure 21. WSE at observation point at the levee setback Alternatives 1 and 2.............................20

Figure 22. WSE at observation point downstream of the levee setback Alternatives 1 and 2...........20

Figure 23. Maximum WSE at the setback observation point (Alternatives 1 and 2).........................21

Figure 24. Change in maximum WSE (base condition minus levee setback alternative) at WSE observation points for levee setback Alternatives 1 and 3

Figure 25. OV (meters/second) of the sinuous channel initial conditions model during the peak discharge.

Figure 26. OV (meters/second) of the sinuous channel Alternative 1 during the peak discharge.

Figure 27. OV (meters/second) of the sinuous channel Alternative 2 during the peak discharge. 
Figure 28. OV (meters/second) of the sinuous channel Alternative 3 during the peak discharge.

\section{Tables}

Table 1. Floodplain roughness values and description..................................................................... 


\section{Preface}

This study was conducted for the Flood and Coastal Systems Research and Development Program under "Evaluation of Levee Setbacks and River Restoration Projects for Flood Risk Reduction.” The program manager was Dr. Cary Talbot (CEERD-HF-HG).

The work was performed by the River Engineering Branch of the Flood and Storm Protection Division (CEERD-HF), U.S. Army Engineer Research and Development Center, Coastal and Hydraulics Laboratory (ERDC-CHL). At the time of publication of this report, Mr. Keith W. Flowers was Chief, River Engineering Branch (CEERD-HFR); Dr. Cary A. Talbot was Chief, Flood and Storm Protection Division (CEERD-HT); and Dr. Julie D. Rosati was the Technical Director for Flood and Coastal Storm Protection (CEERD-HT). The Acting Director of ERDC-CHL was Mr. Jeffrey R. Eckstein.

Special appreciation is extended to Dr. James W. Lewis, River Engineering Branch (CEERD-HFR), for providing technical guidance and support throughout the multiple steps required to complete this study.

The Commander of ERDC was COL Bryan S. Green, and the Director was Dr. David W. Pittman. 


\section{Unit Conversion Factors}

\begin{tabular}{|l|c|l|}
\hline Multiply & By & To Obtain \\
\hline cubic feet per second & 35.314475 & cubic meters per second \\
\hline feet & 0.3048 & meters \\
\hline tons (2,000 pounds, mass) & 907.1847 & kilograms \\
\hline inch & .0254 & meters \\
\hline tons [U.S., 2,000 pounds, mass, (short)] & 1.1023 & metric tons \\
\hline mile & 1.609 & kilometers \\
\hline
\end{tabular}




\section{Introduction}

\subsection{Purpose}

This report describes a hydrodynamic study on levee setback alternatives using numerical models of hypothetical cases. Levee setbacks are projects that move portions of the levee farther away from the river channel and increase the amount of floodplain area that can be accessed by the river during high water events (Dahl et al. 2017). The purpose of this study was to develop two-dimensional (2D) hydrodynamic models with the objective being to simulate hypothetical scenarios to quantify potential effects of levee setbacks on water surface elevation (WSE) and overland velocity (OV) during a large flood event. The model results could provide preliminary insights that may help to consider levee setbacks as an alternative for flood risk management.

\subsection{Background}

A compound channel is composed of the main channel, which conveys base flow and frequency flows up to bankfull conditions, and the overbanks that transport overbank flow during flood conditions. The total conveyance in a compound channel is defined by $\mathrm{Q} / \mathrm{S}^{1 / 2}$, where $\mathrm{Q}$ is the total discharge (cubic feet per second or cubic meters per second) and $\mathrm{S}$ is the energy slope, which is assumed to be equal to the bed slope under uniform flow conditions (Sturm 2001). Discharge is a function of the velocity and cross-sectional area. When the area is increased while the inflow remains unchanged, the water stage is reduced.

A traditional levee is a structure built along a water course with the main purpose of containing, controlling, or diverting the flow of water to reduce flooding (U.S. Army Corps of Engineers Levee Safety Program 2017). Traditional levees tend to narrow the width of the channel's floodplain, creating a compound channel when located on the left and right overbanks and limiting the flood extent. Levee setbacks relocate a portion of a traditional levee farther away from the river channel to provide additional floodplain storage, reducing flood stages (Dahl et al. 2017). Levee setbacks are considered nonstructural flood risk management techniques since they can reduce existing impacts of the levee structures on the natural river and floodplain processes. 
To determine the feasibility of a levee setback alternative, additional considerations such as economic benefits and ecosystem restoration should also be evaluated. More detailed discussions about the benefits of levee setbacks beyond reduced flooding can be found in Dahl et al. (2017) and Smith et al. (2017).

This report investigates the feasibility of levee setbacks in a conceptual manner. The remainder of the report describes the modeling methodology used (Chapter 2), discusses the results (Chapter 3), and provides some concluding remarks (Chapter 4).

\subsection{Approach}

The approach is addressed in Chapter 2 Methodology. 


\section{Methodology}

Numerical flow simulations were conducted for two hypothetical rivers, one with a straight and the other with a sinuous channel. Adaptive Hydraulics (AdH) Version 4.5, a 2D depth-averaged model developed by the U.S. Army Engineer Research and Development Center, was applied for this study. The AdH model is a software package that can describe both saturated and unsaturated groundwater, overland flow, three-dimensional (3D) NavierStokes, and 3D shallow water problems in addition to 2D shallow water problems (Berger et al. 2010). This study used the 2D shallow water equations. To estimate potential impacts of levee setbacks on WSE and OV during a high flow event, two alternatives for the straight channel and three alternatives for the sinuous channel were evaluated.

\subsection{Geometry of straight channel alternatives}

Figure 1 shows the base condition for the straight trapezoidal channel. The trapezoidal channel is 137 meters $(\mathrm{m}$ ) (449 feet [ft]) wide across the top and $4 \mathrm{~m}(13 \mathrm{ft})$ deep with $1 \mathrm{~V}: 9 \mathrm{H}$ side slopes. The levees are parallel to the channel and are located approximately $154 \mathrm{~m}(505 \mathrm{ft})$ from the edge of the channel. The model domain is approximately 10.3 kilometers $(\mathrm{km})$ (6.4 miles) long. The cross section is most clearly visible in the lower lefthand corner of Figure 1, although the vertical scale is exaggerated relative to the horizontal scale. The channel longitudinal slope is defined by the difference between the upstream and downstream channel bottom elevations divided by the channel length. The longitudinal slope of the straight channel is $0.0004 \mathrm{~m} / \mathrm{m}$. The valley slope is defined by the difference between the upstream and downstream overbank elevations divided by the overbank length. The valley slope for the straight channel case is $0.0004 \mathrm{~m} / \mathrm{m}$ (the same as the longitudinal slope).

Note that in all of the mesh figures, there are areas with higher-resolution mesh elements that appear as thick, black lines in the figure. These black lines are due to the closely spaced elements in the computational mesh. Terrain features and elevations are indicated by the colors, as shown in the legend. The higher resolution may only be required for certain alternatives, but the same mesh was used for all alternatives to provide consistency in comparisons. 
Figure 1. Straight channel mesh showing base condition.

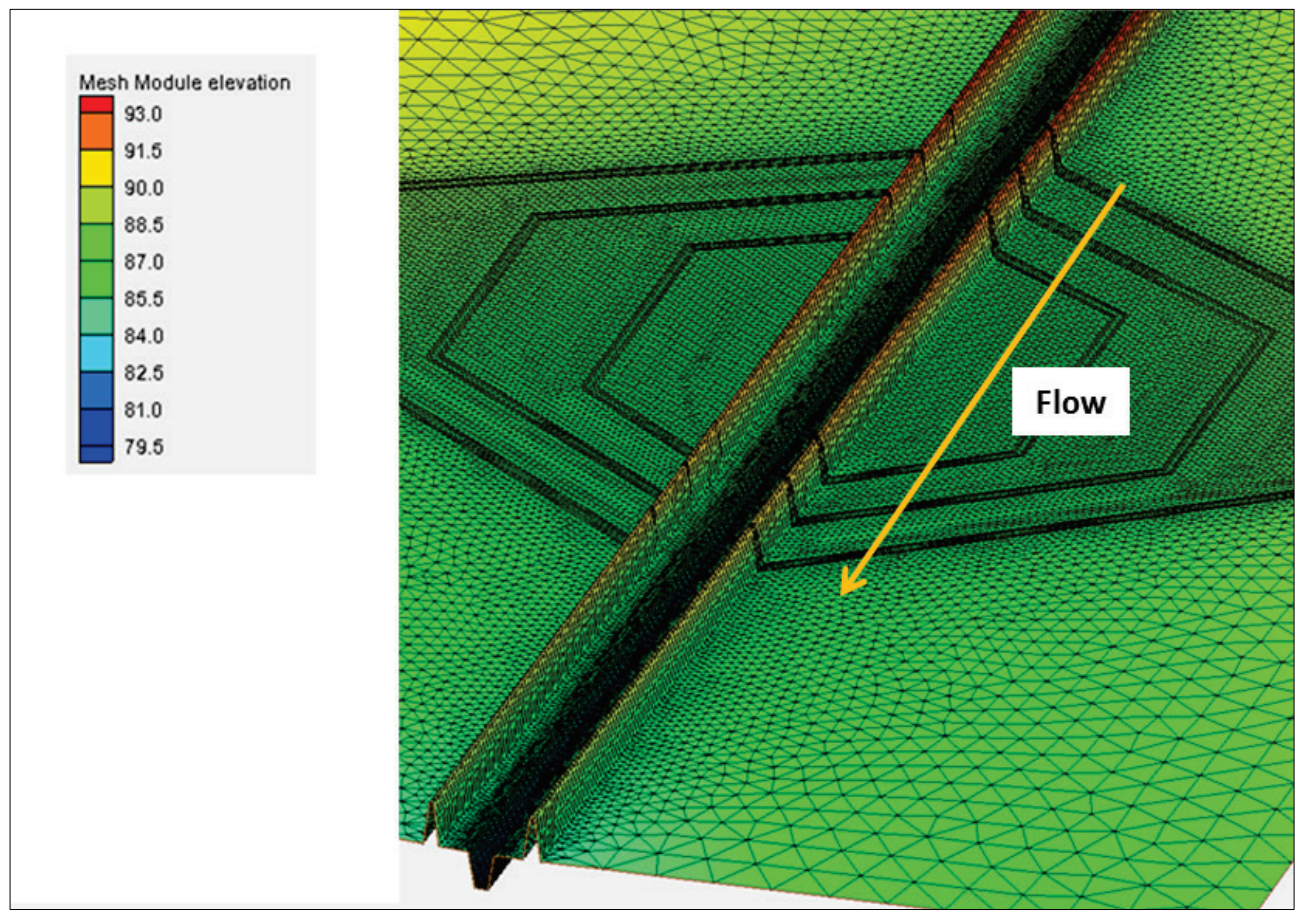

Figure 2 shows the straight channel Alternative 1 . The levee is set back approximately $1,020 \mathrm{~m}(3,346 \mathrm{ft})$ from the edge of the channel on both the left and right banks with $30^{\circ}$ flow transitions. The area of the levee setback including the left and the right banks is approximately $3.48 \mathrm{~km}^{2}\left(1.34\right.$ miles$\left.^{2}\right)$.

Figure 2. Straight channel mesh showing Alternative 1.

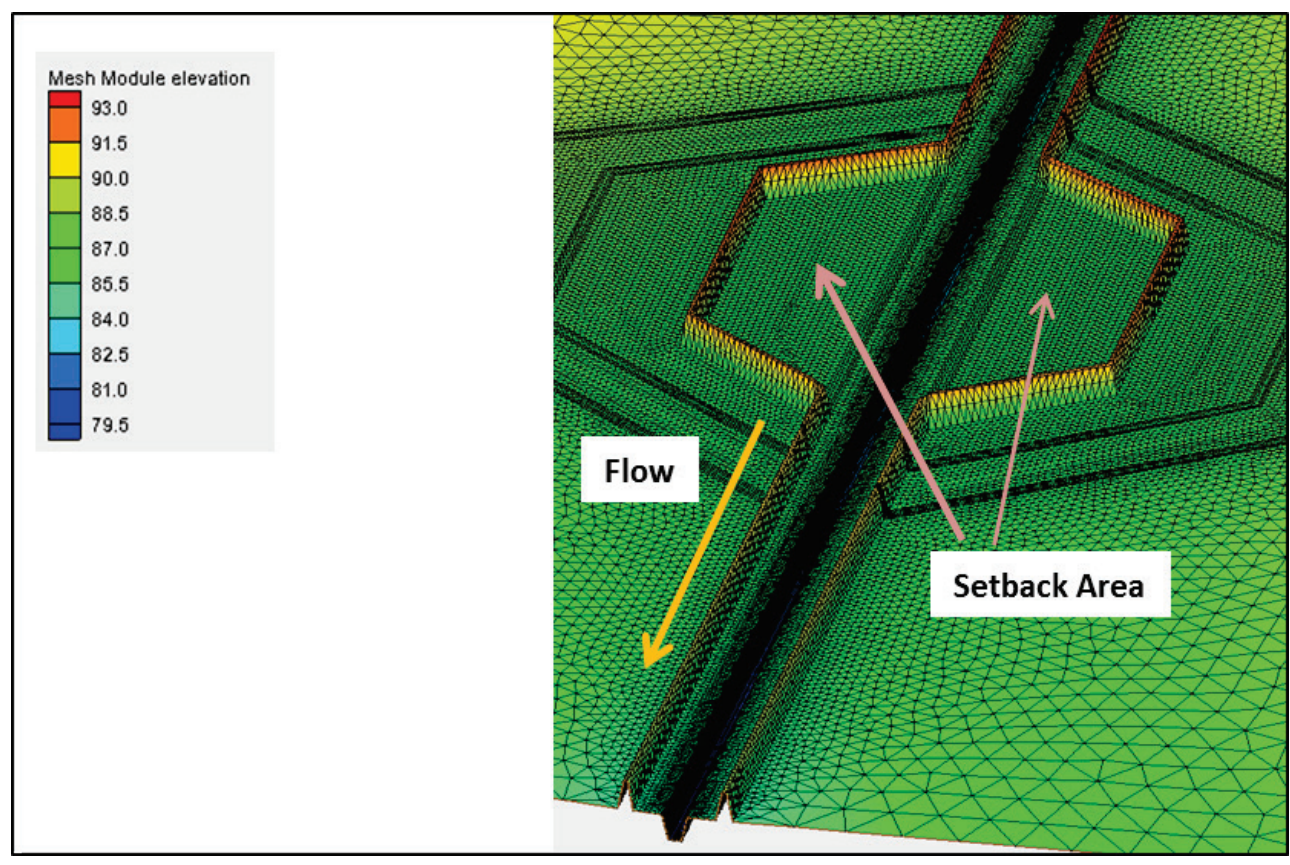


Figure 3 shows the straight channel Alternative 2. The levee setback is located only on the right descending bank, approximately $1,810 \mathrm{~m}(5,939 \mathrm{ft})$ from the edge of the channel with $30^{\circ}$ flow transitions. The area of the setback is approximately $4.15 \mathrm{~km}^{2}\left(1.6\right.$ miles$\left.^{2}\right)$. Alternative 2 is slightly (16\%) larger than Alternative 1 in terms of setback area. The main difference between Alternative 1 and Alternative 2 is that the levee setback area in Alternative 1 is distributed on both the left and right banks while in Alternative 2 the setback area is located only on the left bank. The purpose of modeling both alternatives was to compare similar setback areas with different layouts and their impact on the WSE for a large flow event in a straight channel.

Figure 3. Straight channel mesh showing the Alternative 2.

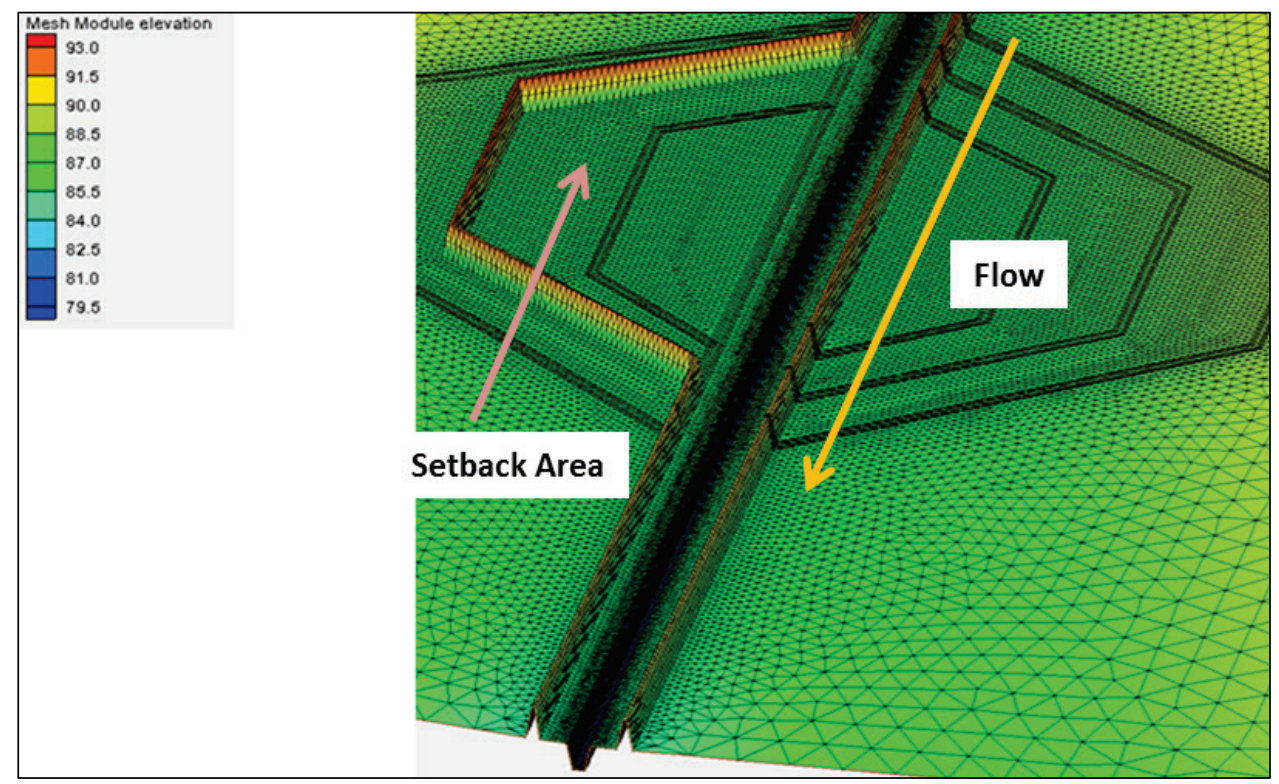

\subsection{Geometry of sinuous channel alternatives}

The sinuous trapezoidal channel has the same width, depth, and side slopes as the straight channel and a sinuosity of 1.2. The longitudinal and valley slopes are approximately $0.00033 \mathrm{~m} / \mathrm{m}$ and $0.0004 \mathrm{~m} / \mathrm{m}$, respectively.

Figure 4 shows the sinuous channel base condition mesh. As in the straight channel alternatives, the levees are located $154 \mathrm{~m}(505 \mathrm{ft})$ from the edge of the channel. Figure 5 shows the sinuous channel Alternative 1 . The levee setback is located on the left bank, approximately 1,197 m (3,926 ft) from the edge of the channel. Figure 6 shows the sinuous channel Alternative 2. This levee setback is also located at the left bank, but it is much smaller, 
with a maximum distance from the edge of the channel of approximately $584 \mathrm{~m}(1,915 \mathrm{ft})$.

Figure 7 shows the sinuous channel, Alternative 3. This alternative has the same characteristics as Alternative 1 except that the levee setback is located at the right bank.

Alternative 1 and Alternative 2 were chosen to compare how the change of levee setback area on the right bank of the inside meander bend would impact the WSE for a large flow event in a sinuous channel. Alternative 3 has the same setback area as Alternative 1 and is located on the left bank of the inside meander bend.

Figure 4. Sinuous channel mesh showing the base condition.

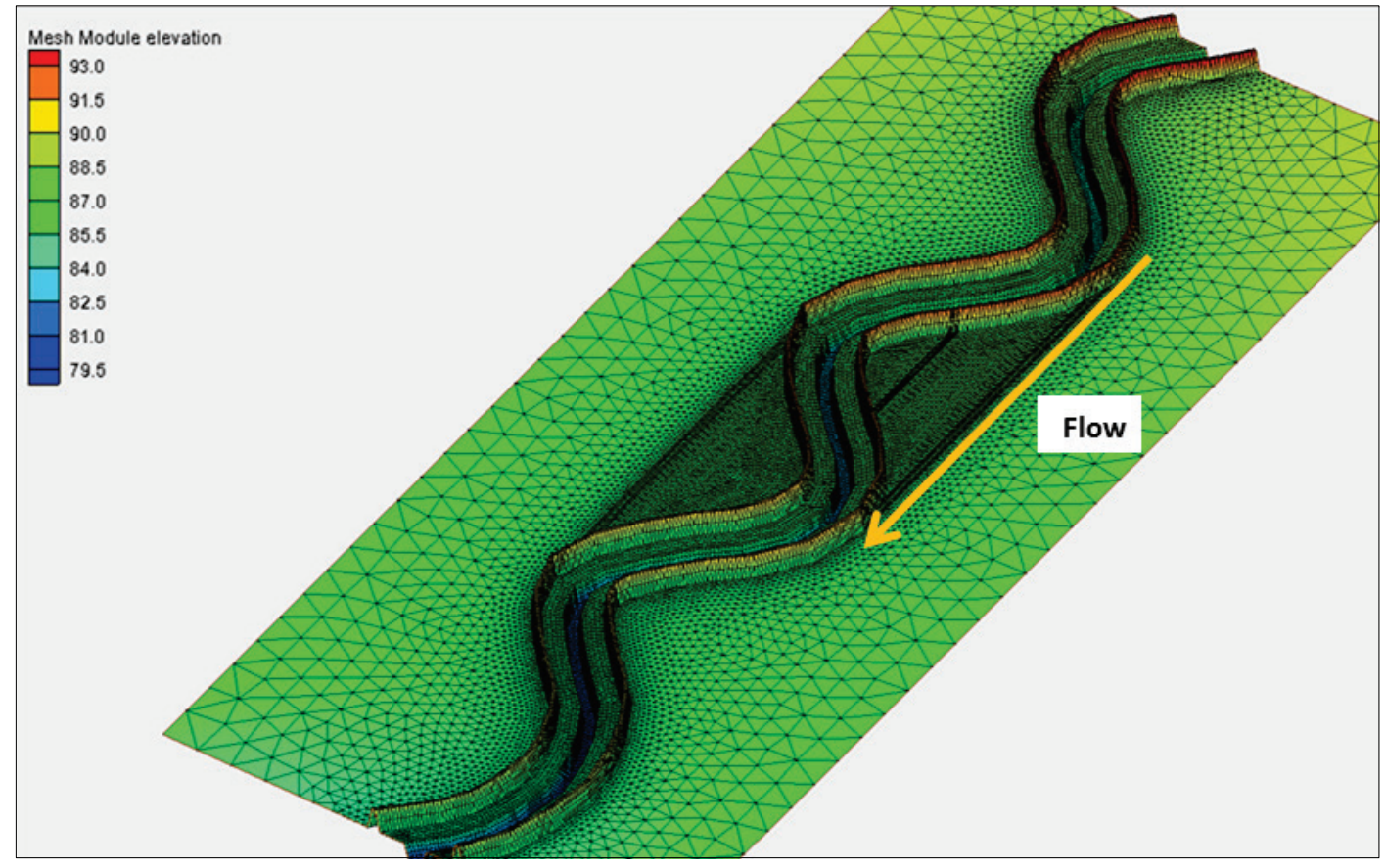


Figure 5. Sinuous channel mesh showing the Alternative 1.

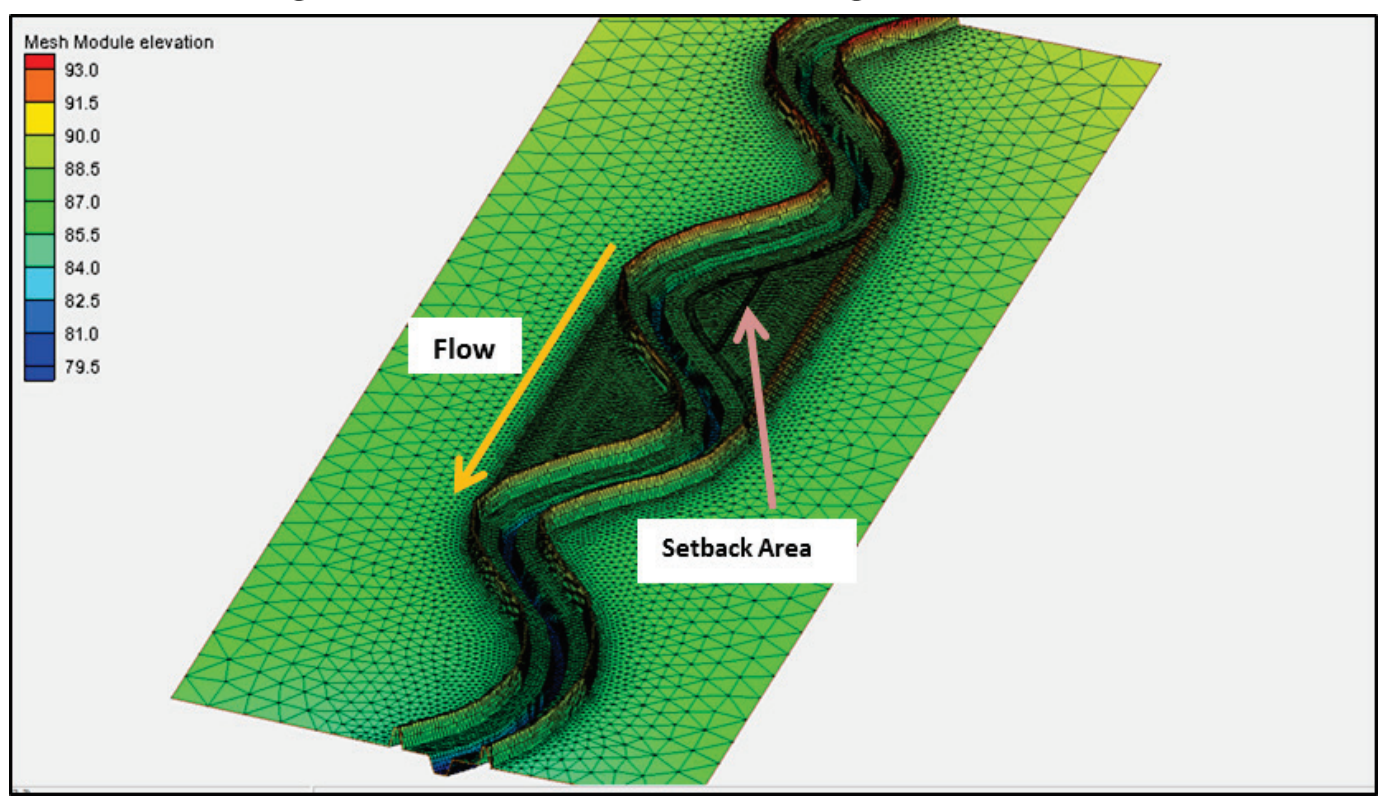

Figure 6. Sinuous channel mesh showing the Alternative 2.

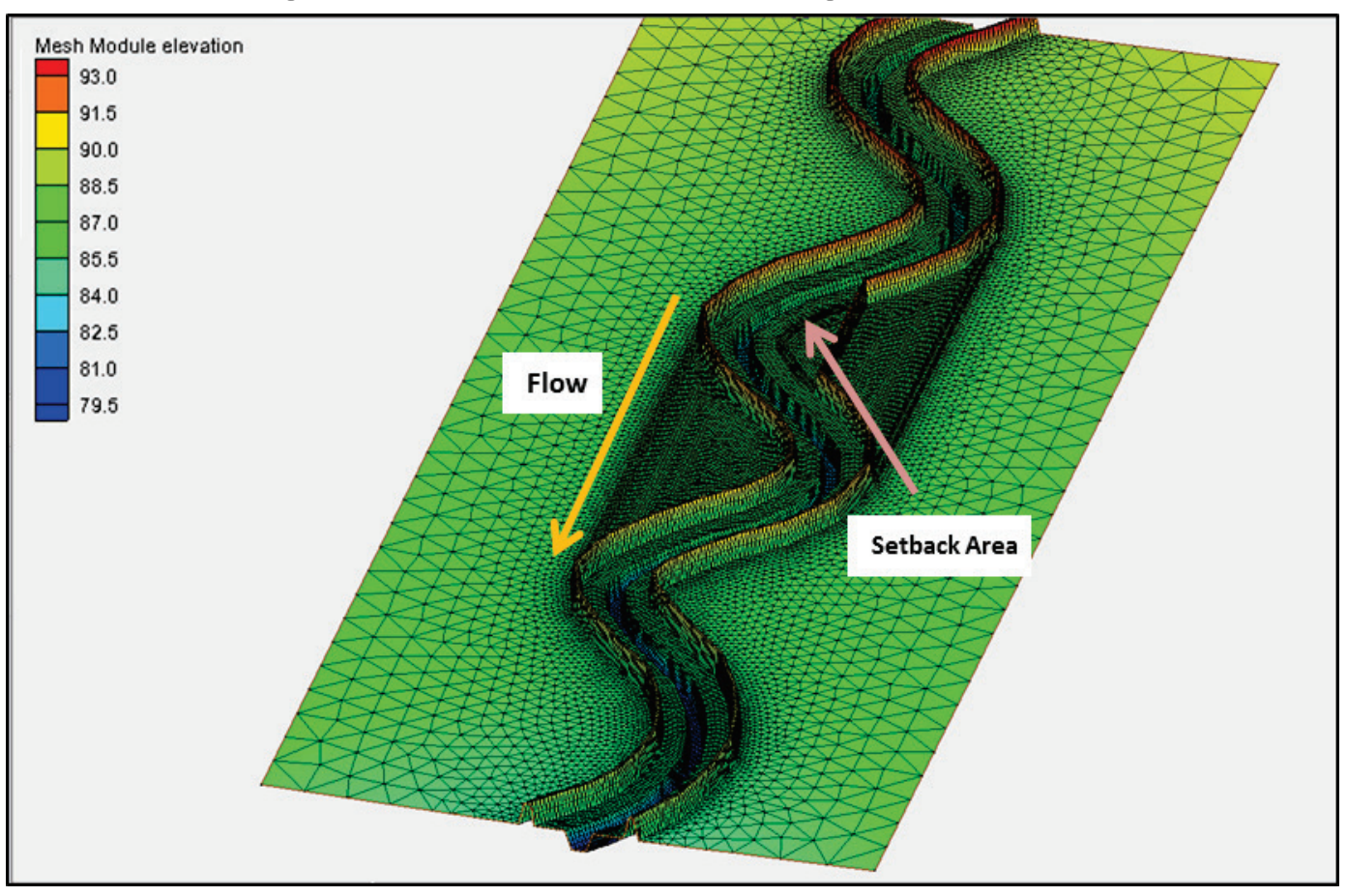


Figure 7. Sinuous channel mesh showing the Alternative 3.

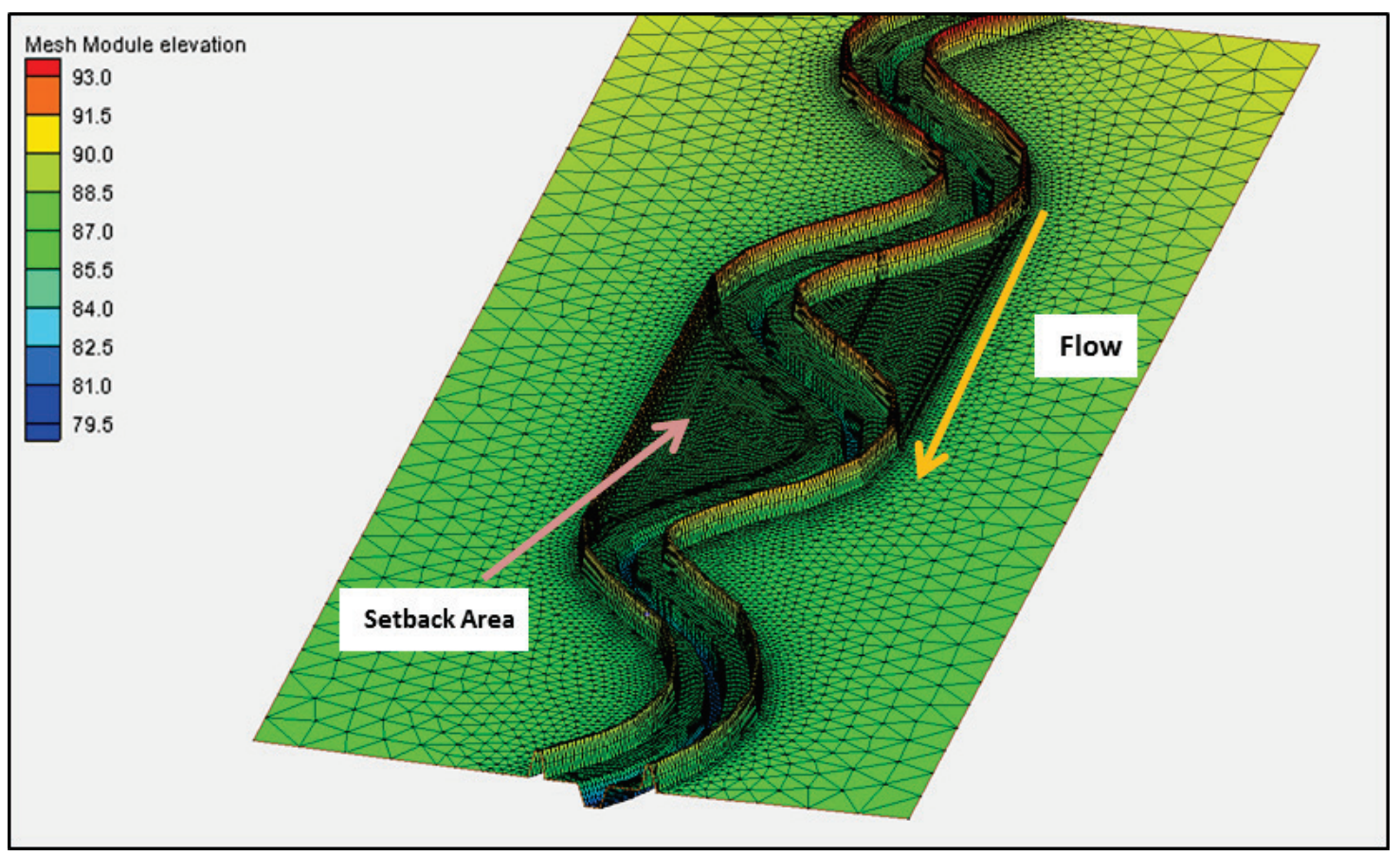

\subsection{Hydraulic model parameters}

The channel roughness coefficient for all the straight and sinuous channel models is 0.025 . Three different floodplain roughness values were used to assess the potential impact of various vegetation types. Table 1 gives the floodplain roughness coefficients used in the hydrodynamic numerical simulations. A roughness value of 0.035 was assigned to the levee, to represent a typical grass cover.

Table 1. Floodplain roughness values and description.

\begin{tabular}{|l|l|}
\hline Roughness Value & Description \\
\hline 0.035 & Grass \\
\hline 0.040 & Mature field crops \\
\hline 0.050 & Light bush and trees, in summer \\
\hline
\end{tabular}

Source: Chow (1959)

The upstream boundary condition assigned to all the models was a unit hydrograph developed using the Natural Resources Conservation Service (NRCS) unit hydrograph method. Figure 8 shows the unit hydrograph. The peak flow of 3,600 cubic meters per second $(\mathrm{cms})(127,000$ cubic feet per second [cfs]) is large enough to inundate the floodplain and almost overtop the levees. 
The scale used for the hypothetical models is similar to the Savannah River near Augusta, GA. The U.S. Geological Survey (USGS) gage 02197000 at Augusta, GA, has recorded peak flows up to 9,919 cms (350,000 cfs) before the construction of flow control dams. The New Savannah Bluff Lock and Dam (NSBLD) began operations in 1937. After the construction of the NSBLD, the maximum peak flows ranged from $2834 \mathrm{cms}$ to $7085 \mathrm{cms}(100,000 \mathrm{cfs}$ to $250,000 \mathrm{cfs})$. The J. Strom Thurmond Dam began operations in 1954. Since its construction, the maximum peak flows have remained under $2,834 \mathrm{cms}(100,000 \mathrm{cfs})$ as shown in Figure 9.

Figure 8. Synthetic unit hydrograph used in the dynamic simulations.

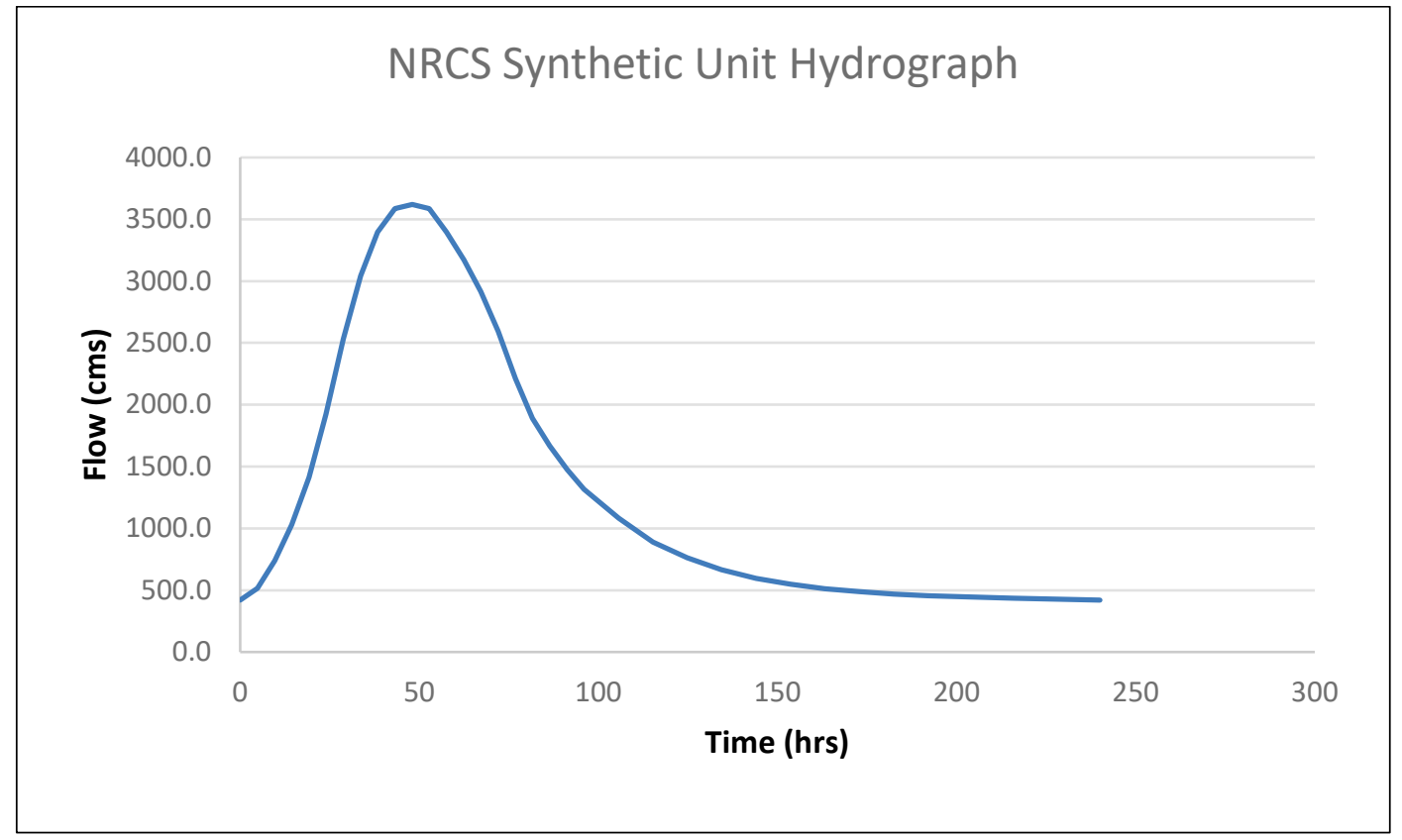


Figure 9. Savannah River annual peak flows at USGS gage near Augusta, GA.

(Source: USGS Water Resources)

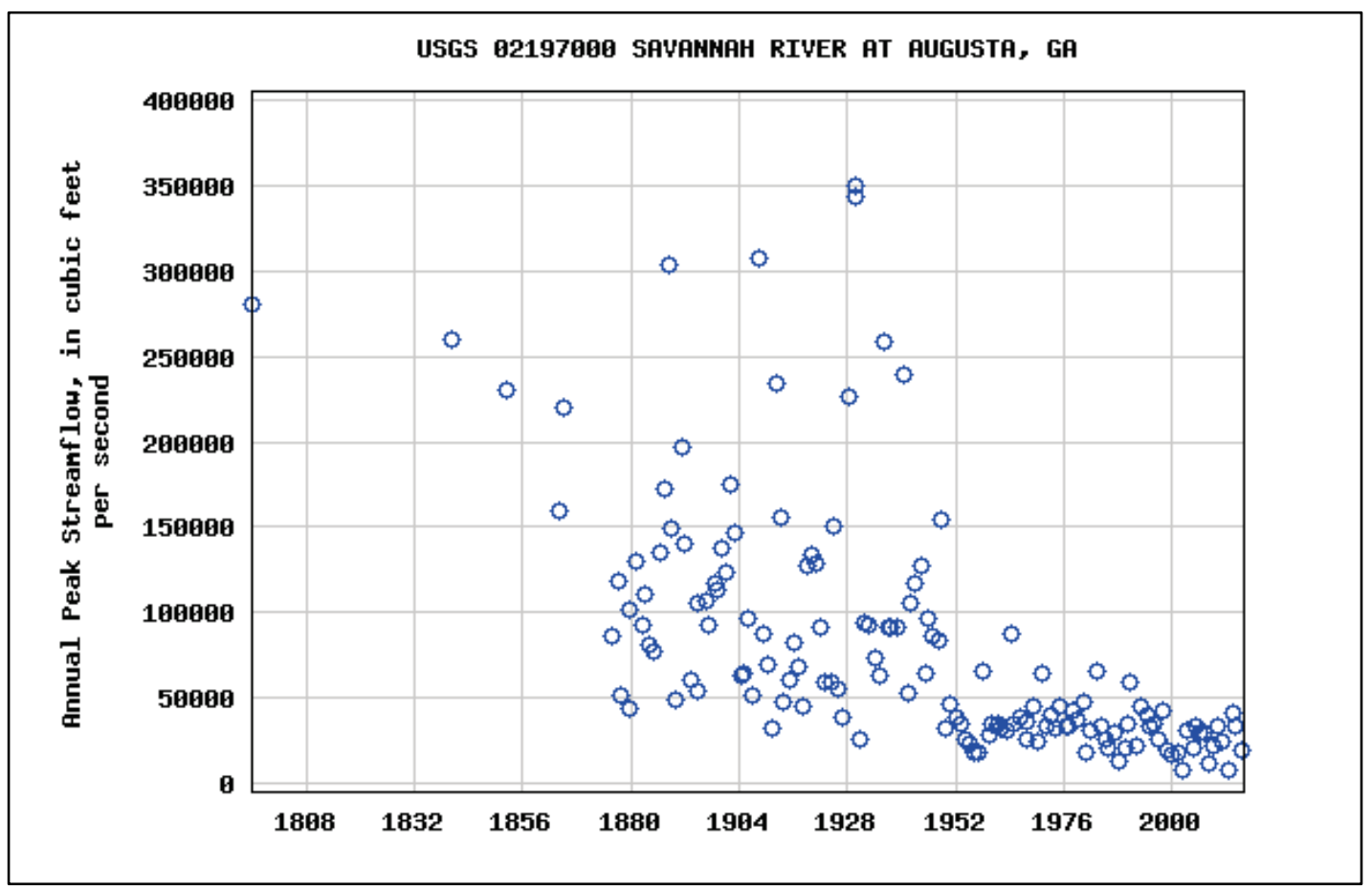

The downstream boundary condition assigned to the models was a predetermined WSE. The models were first run with a fixed WSE at the downstream end to estimate the depth calculated by the numerical model at a node close to the downstream boundary. Then, the depth calculated by the numerical model was used to calculate the WSE at the downstream boundary assuming uniform flow conditions (i.e., the energy slope and the bed slope are the same). The downstream boundary location is located far enough downstream (at least $4 \mathrm{~km}$ [2.5 miles]) from the levee setback areas that it does not impact results at the setback areas. Therefore, the same tailwater was used for all the models. The model results are intended to show a difference between a base condition (original levee scenario) and a levee setback alternative. 


\section{Model Simulations and Results}

\subsection{Straight channel dynamic simulations}

Three hypothetical models of a straight channel, including the base condition (original levee without setbacks) and two levee setback alternatives, were constructed to identify potential impacts of levee setbacks on WSE and OV. The orange lines in Figure 10 represent the original conditions. The light-purple lines represent Alternative 1, and the dark-blue line represents Alternative 2. The WSE was extracted from the model results at three locations: upstream of the levee setbacks, at the levee setback, and downstream of the levee setback. These monitoring locations are shown in Figure 10. The locations are represented with a red horizontal line. The WSE was extracted from a node located approximately at the center of the channel for each of the three locations.

Figure 10. Levee setback alternatives and WSE observation points for the straight channel models. Only the central portion of the model domain is shown.

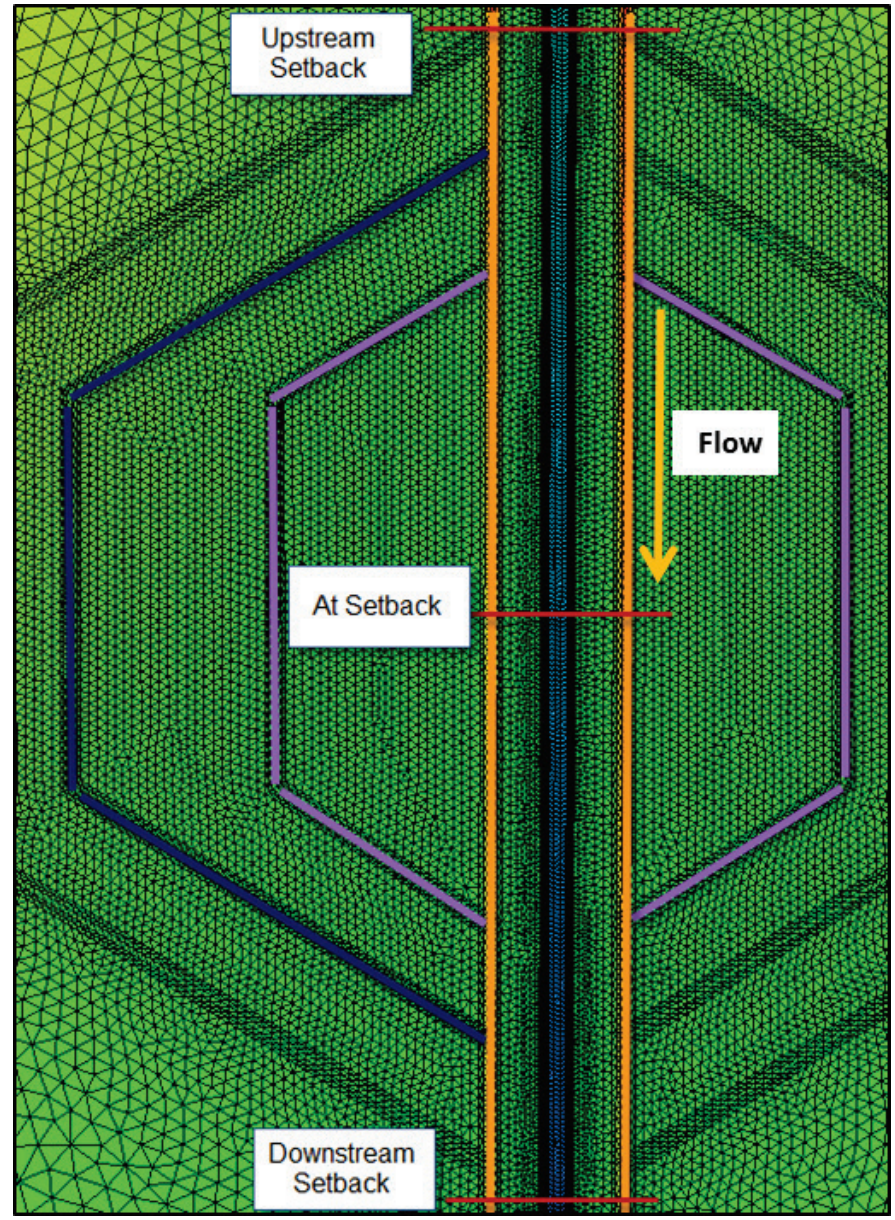


The upstream setback WSE observation point is located approximately $930 \mathrm{~m}(3,050 \mathrm{ft})$ upstream of the start of Alternative 1 and $480 \mathrm{~m}(1,574 \mathrm{ft})$ upstream of the start of Alternative 2. The downstream setback WSE observation point is located approximately 1,030 $\mathrm{m}(3,378 \mathrm{ft})$ downstream of the end of Alternative 1 and $580 \mathrm{~m}(1,902 \mathrm{ft})$ downstream of the end of Alternative 2. The Downstream Setback observation point is also approximately $3 \mathrm{~km}$ (1.9 miles) upstream of the end of the model domain. Figure 11 shows the WSE at the upstream observation point for the base condition, Alternative 1, and Alternative 2 during the higher flows of the synthetic unit hydrograph with a floodplain roughness of 0.040 .

Figure 11. WSE at the observation point upstream of the levee setback alternatives.

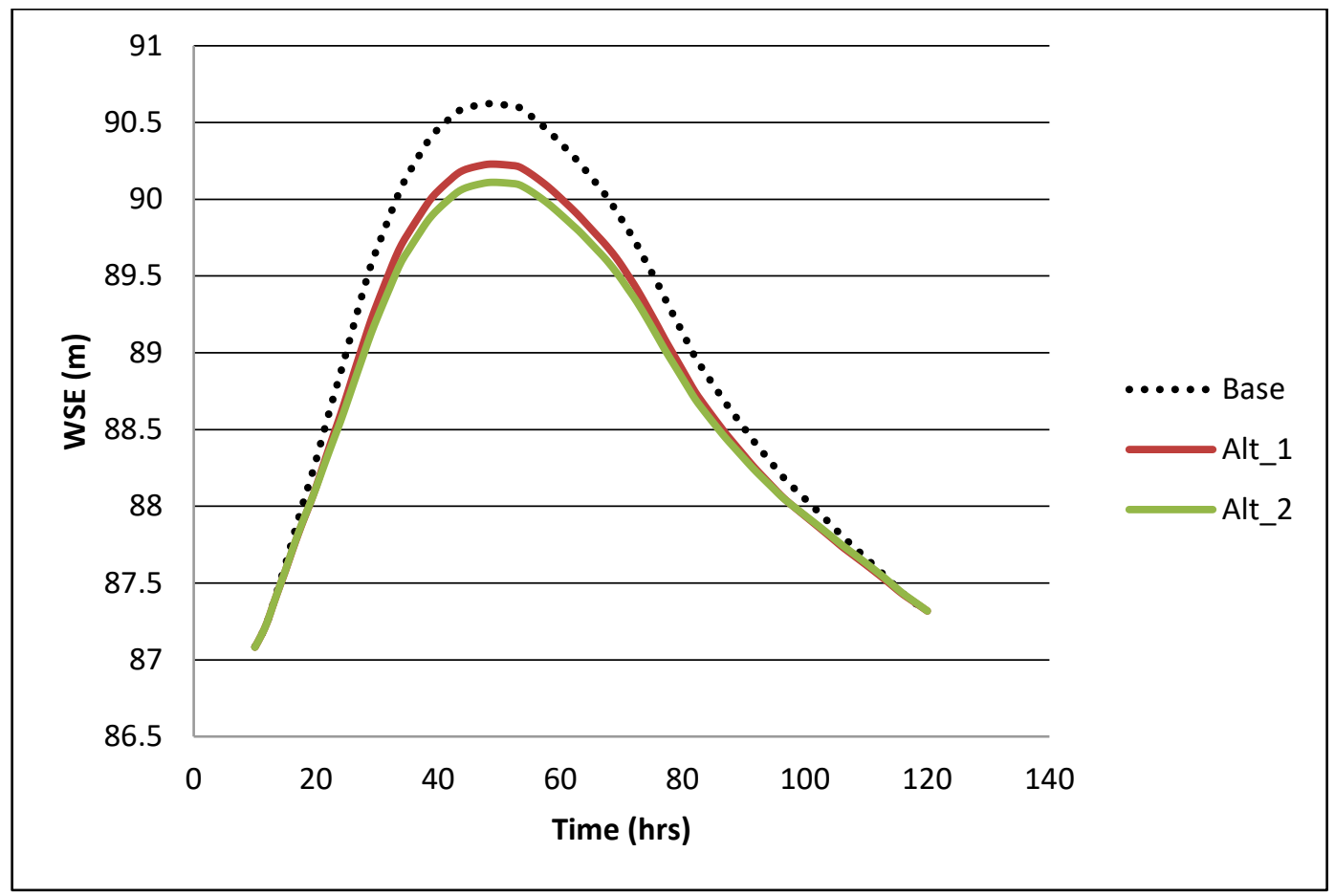

The maximum WSE drops approximately $0.4 \mathrm{~m}(1.31 \mathrm{ft})$ for Alternative 1 and $0.5 \mathrm{~m}(1.64 \mathrm{ft})$ for Alternative 2 when compared with the base condition using a floodplain roughness of 0.040. As mentioned in Section 2.1.1, the levee setback area of the Alternative 2 is approximately $16 \%$ larger than the levee setback area of the Alternative 1. According to Figure 11, an increase in levee setback area also increases the reduction in the WSE under the same flow and roughness conditions.

Figure 12 shows the WSE for the base condition, Alternative 1, and Alternative 2 during the higher flows of the synthetic unit hydrograph with a floodplain roughness of 0.040 at the WSE observation point at the levee setbacks. 
Figure 12. WSE at the observation point at the levee setback location.

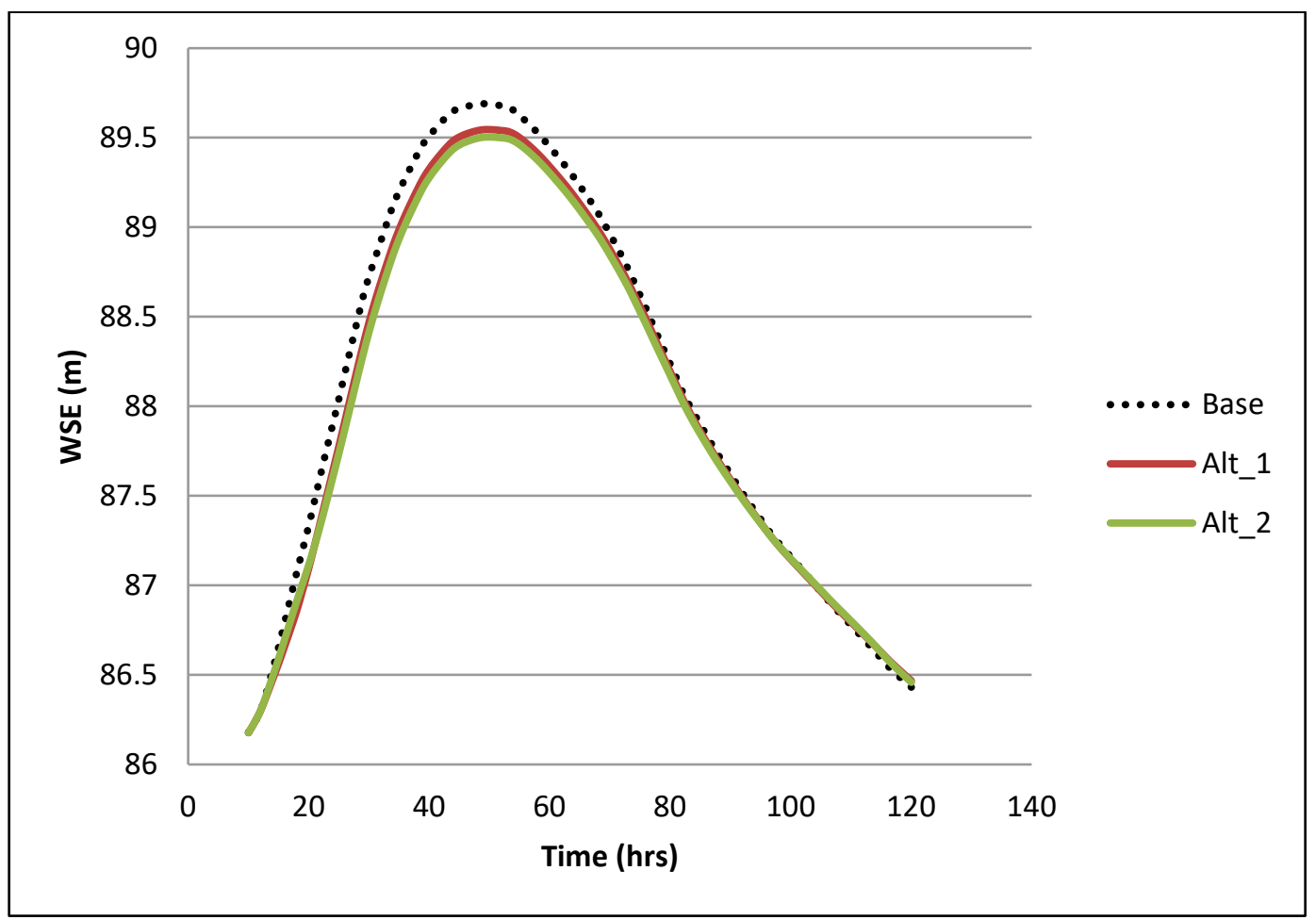

Figure 13. WSE at the observation point downstream of the levee setback alternatives.

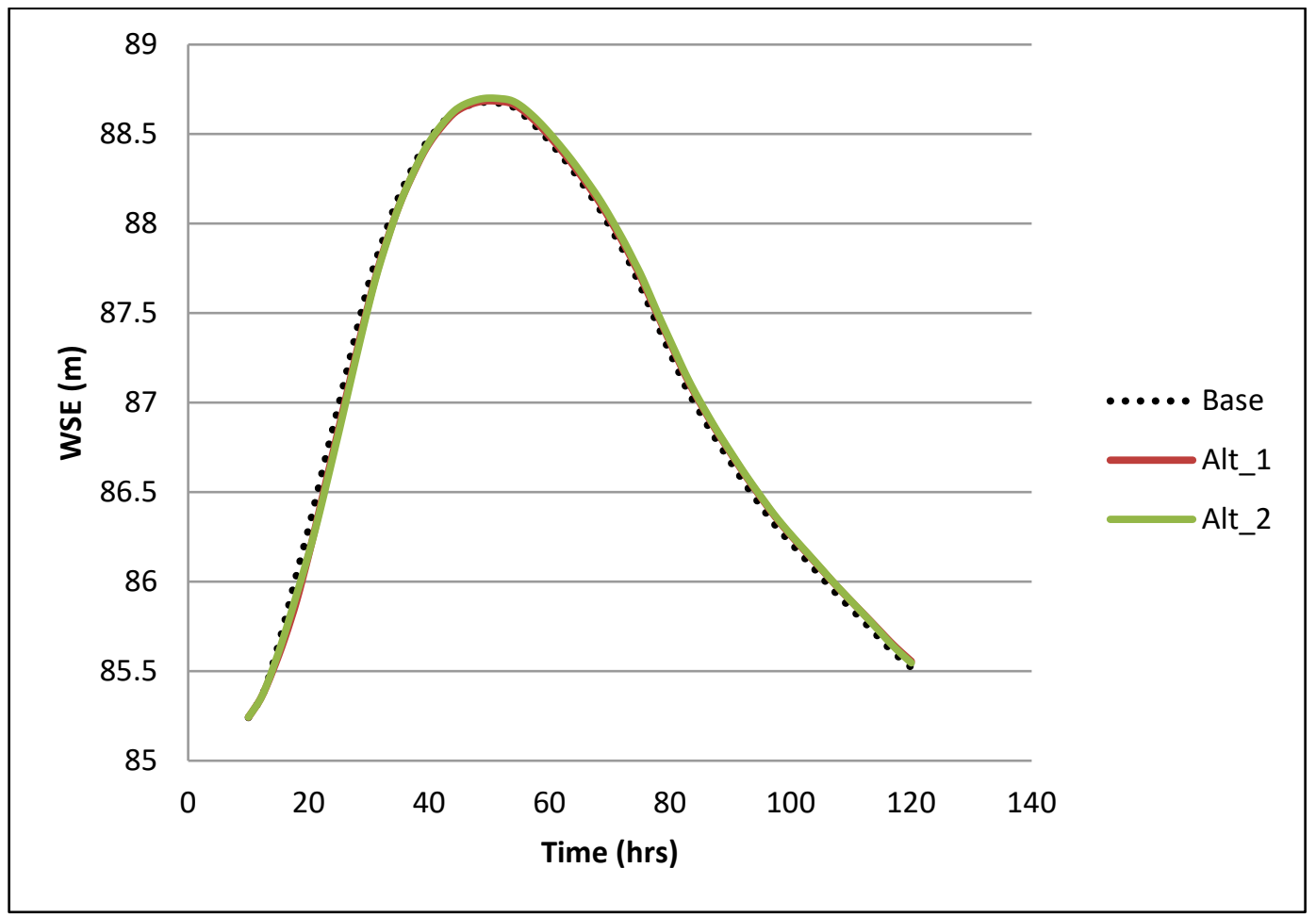


The maximum WSE at the levee setback observation point drops approximately $0.1 \mathrm{~m}(0.33 \mathrm{ft})$ for Alternative 1 and $0.2 \mathrm{~m}(0.66 \mathrm{ft})$ for Alternative 2 when compared with the base condition using a floodplain roughness of 0.040. Results shown in Figure 12 suggest that there is a reduction in WSE at the levee setback area, but it is slightly smaller than the reduction in WSE at the upstream observation point.

Figure 13 shows the WSE for the base condition, Alternative 1, and Alternative 2 during the higher flows of the synthetic unit hydrograph with a floodplain roughness of 0.040 at the WSE observation point downstream of the levee setback. The WSE of the levee setback alternatives at the observation point downstream of the levee setbacks are nearly identical as the WSE of the base condition model. The results shown in Figures 11, 12, and 13 indicate that the more significant impact in the WSE occurs upstream of the levee setbacks and decreases in the downstream direction.

Figure 14 compares the maximum WSE for multiple roughness coefficients at the WSE observation point at the setbacks. Results shown in Figure 14 indicate that the impact of a levee setback on the WSE could be slightly reduced by an increase in the floodplain roughness. The impact of floodplain roughness on WSE is approximately twice that of the setback in these scenarios.

Figure 14. Maximum WSE at the setback observation point.

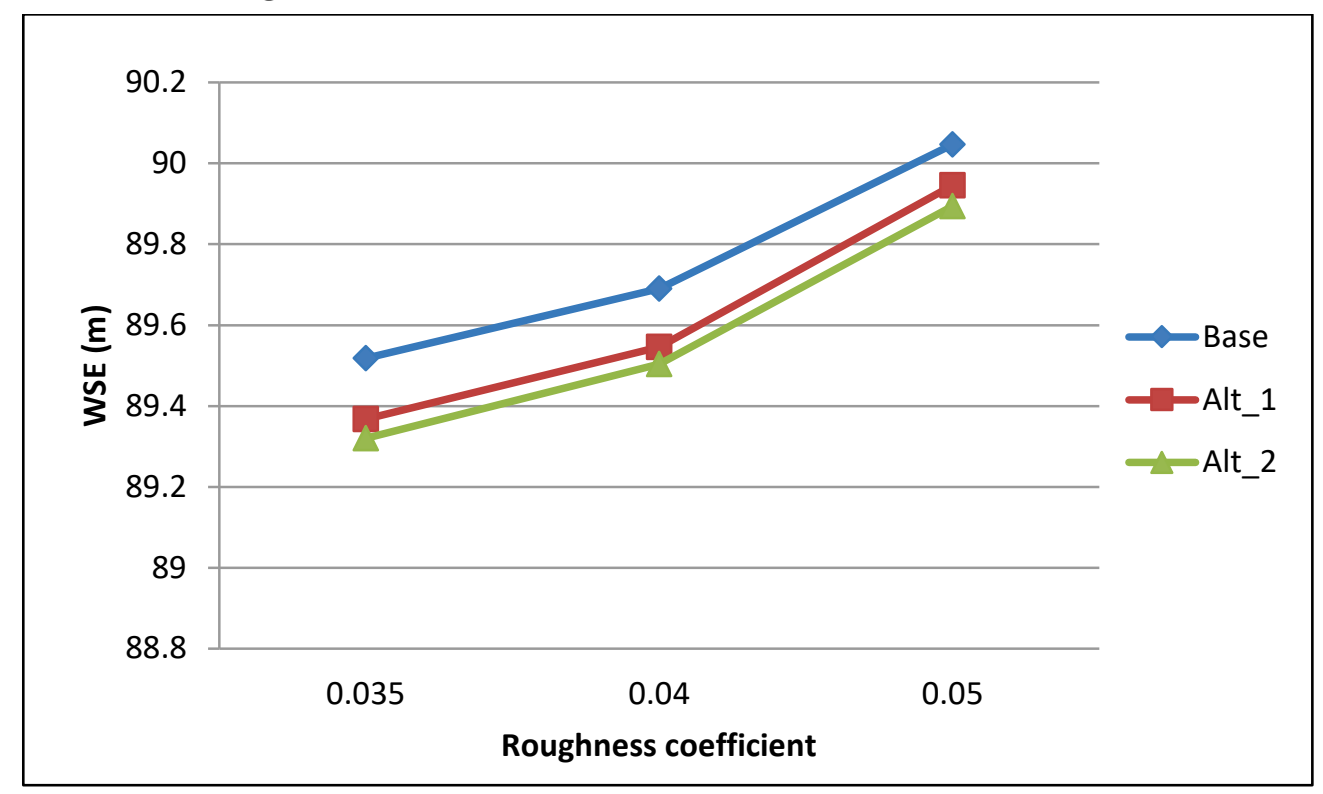


Figure 15 shows the depth-averaged OV of the base condition model for the peak discharge. The velocity in the channel is approximately $3 \mathrm{~m} / \mathrm{s}$ $(9.84 \mathrm{ft} / \mathrm{s})$, and the velocities in the overbanks are approximately $1.2 \mathrm{~m} / \mathrm{s}$ $(3.94 \mathrm{ft} / \mathrm{s})$ for the peak discharge and an overbank roughness coefficient of 0.040.

Figure 15. Overland velocity (meters/second) of the base condition model during the peak discharge.

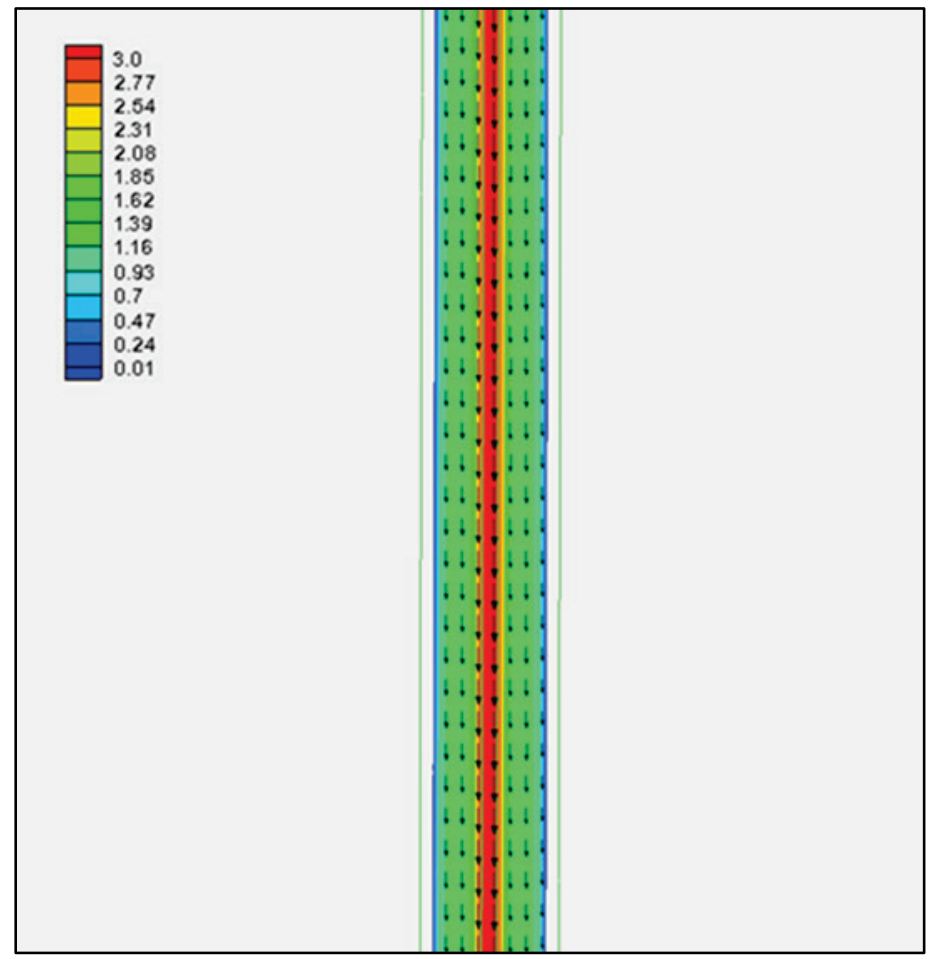

Figure 16 and Figure 17 show the depth-averaged overland velocities of levee setback Alternatives 1 and 2 for the peak discharge with an overland roughness coefficient of 0.040 . The $\mathrm{OV}$ decreases in the channel and floodplain within the levee setback area for both alternatives. The reduction in velocity along the toe of the levee setbacks can also reduce shear stresses associated with large flows. Conversely, the velocity increases at the upstream WSE observation point by approximately $6 \%$ for Alternative 1 and $9 \%$ for Alternative 2 when compared with the base condition. This result is consistent with the principle of conservation of mass. If the same amount of flow is occurring with a lower WSE and lower cross-sectional area, then the velocity of water will increase. 
Figure 16. OV (meters/second) of the levee setback Alternative 1 during the peak discharge.

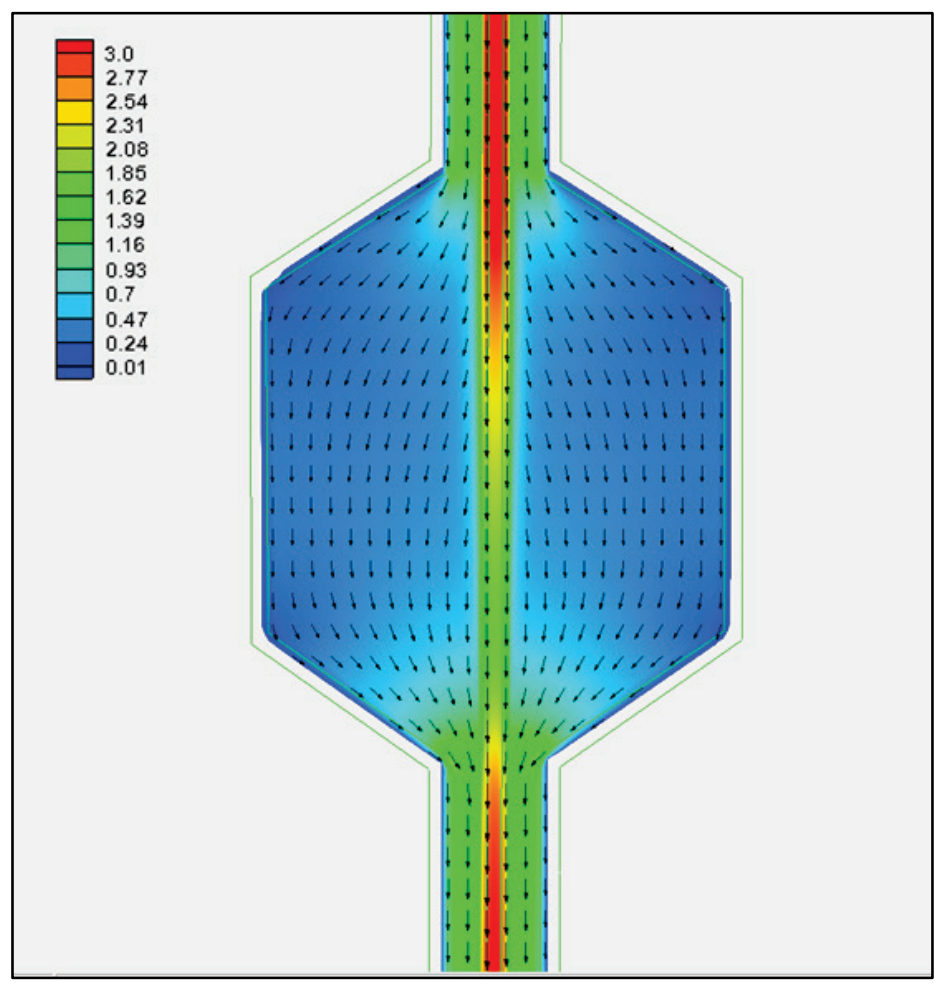

Figure 17. OV (meters/second) of the levee setback Alternative 2 during the peak discharge.

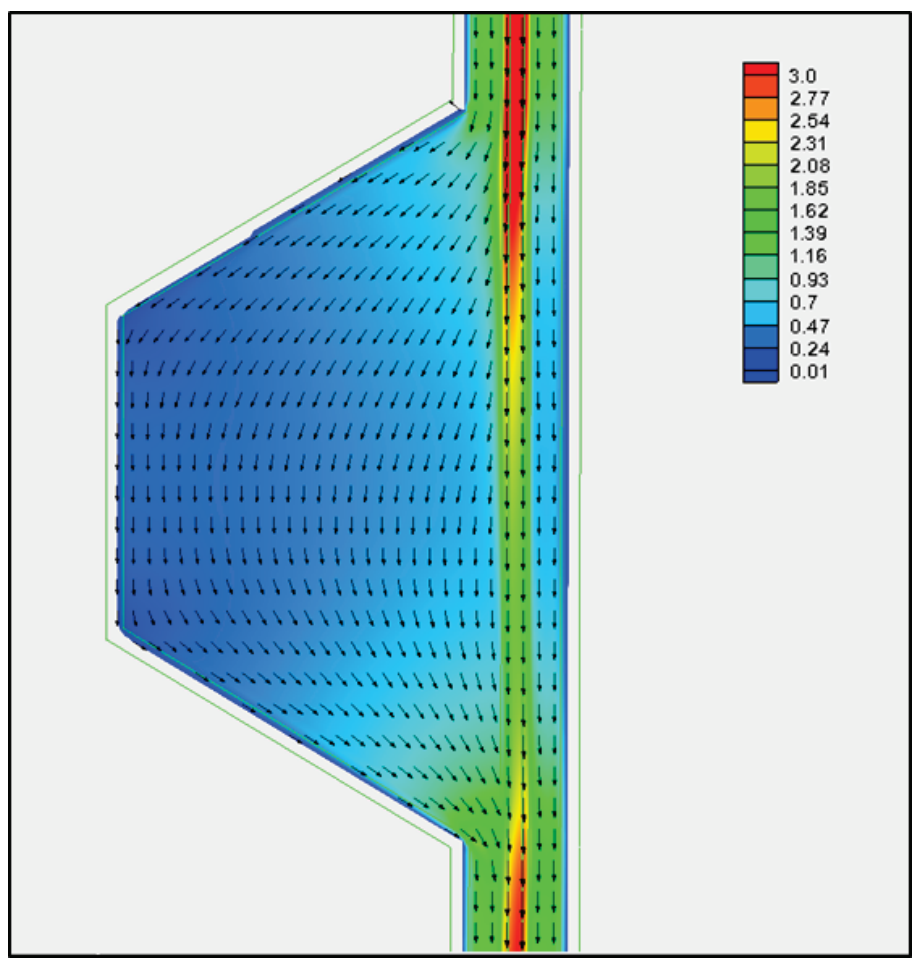




\subsection{Sinuous channel dynamic simulations}

This study also included four hypothetical models of a sinuous channel, including the base condition (original levee without setbacks) and three levee setback alternatives. The models were constructed with the same objective as the straight channel models: to identify potential impacts of levee setbacks on WSE and OV. The orange lines in Figure 18 represent the base condition. The dark-blue line represents Alternative 1 and the light-purple line represents Alternative 2. The WSE was extracted from the model results at three locations: upstream of the levee setbacks, at the levee setback, and downstream of the levee setback. The locations are also shown on Figure 18. The locations are represented with a red horizontal line. The WSE was extracted from a node located approximately at the center of the channel for each of the three locations. The levee setback area of Alternative 1 is approximately 80\% larger than the levee setback area of Alternative 2.

Figure 18. WSE observation points and levee setback Alternatives 1 and 2 for the sinuous channel. Only the central portion of the model domain is shown.

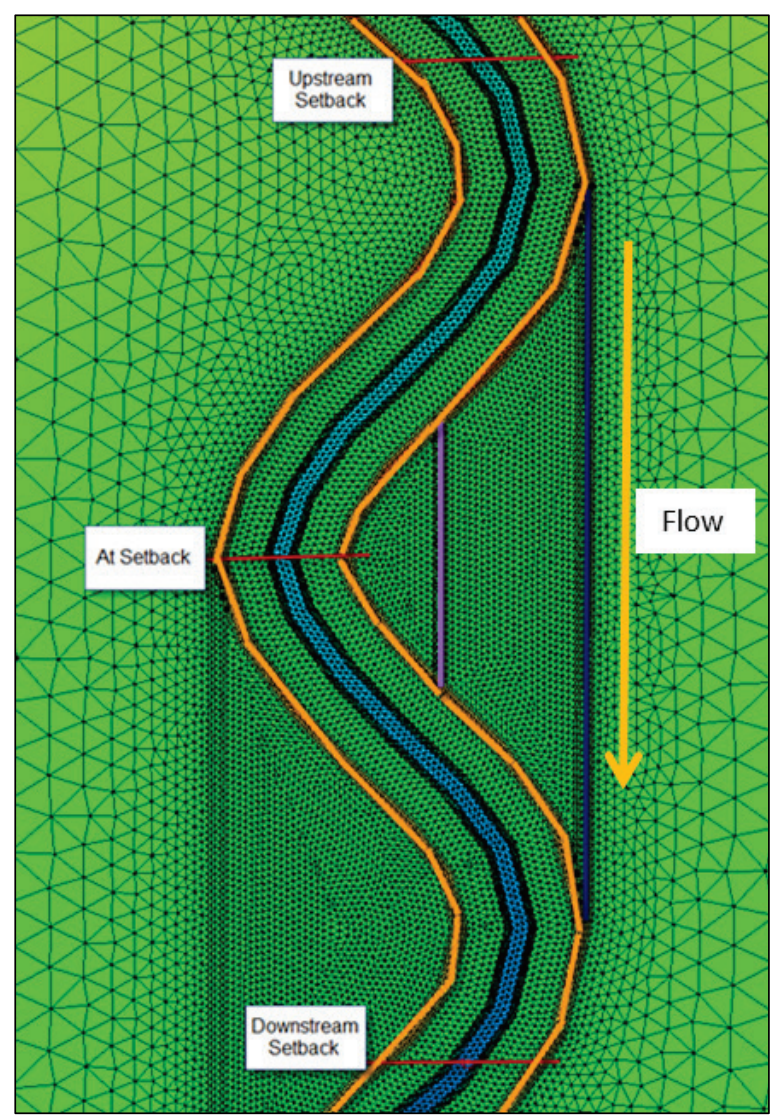


Alternative 3 is located on the right bank, downstream of Alternatives 1 and 2. Therefore, different locations for the WSE observation points have been assigned to this alternative. Figure 19 shows Alternative 3 represented with a light-gray line, the base condition represented with orange lines and the WSE observation points. Since the only difference between Alternative 1 and Alternative 3 is that Alternative 1 is located at the left bank, the upstream and downstream WSE observation points for both alternatives are located approximately $570 \mathrm{~m}(1,870 \mathrm{ft})$ upstream of the start of the levee setback and $500 \mathrm{~m}(1,640 \mathrm{ft})$ downstream of the end of the levee setback. The downstream setback observation point is approximately $3 \mathrm{~km}$ (1.9 miles) upstream of the end of the model domain. For Alternative 2, the upstream WSE observation point is located approximately $1,380 \mathrm{~m}(4,526 \mathrm{ft})$ upstream of the start of the levee setback, and the downstream WSE observation point is located approximately $1,400 \mathrm{~m}$ (4,592 ft) downstream of the end of the levee setback.

Figure 19. WSE observation points and levee setback Alternative 3 for the sinuous channel. Only the central portion of the model domain is shown.

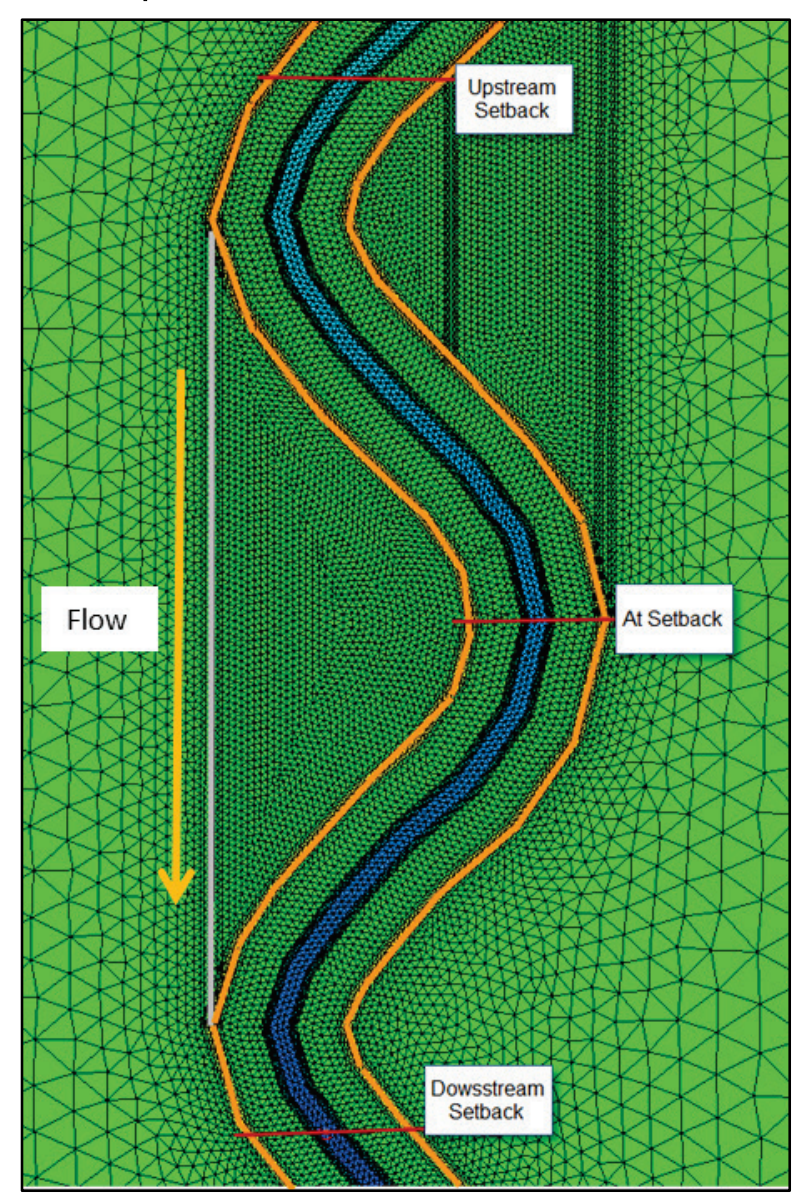


Figure 20 shows the WSE at the observation point upstream of the levee setbacks for the base condition, Alternative 1, and Alternative 2 during the higher flows of the synthetic unit hydrograph with a floodplain roughness of 0.040. The maximum WSE drops approximately $0.5 \mathrm{~m}(1.64 \mathrm{ft})$ for Alternative 1 and $0.2 \mathrm{~m}$ ( $0.66 \mathrm{ft}$ ) for Alternative 2 when compared with the base condition.

Figure 20. WSE at observation point upstream of the levee setback Alternatives 1 and 2.

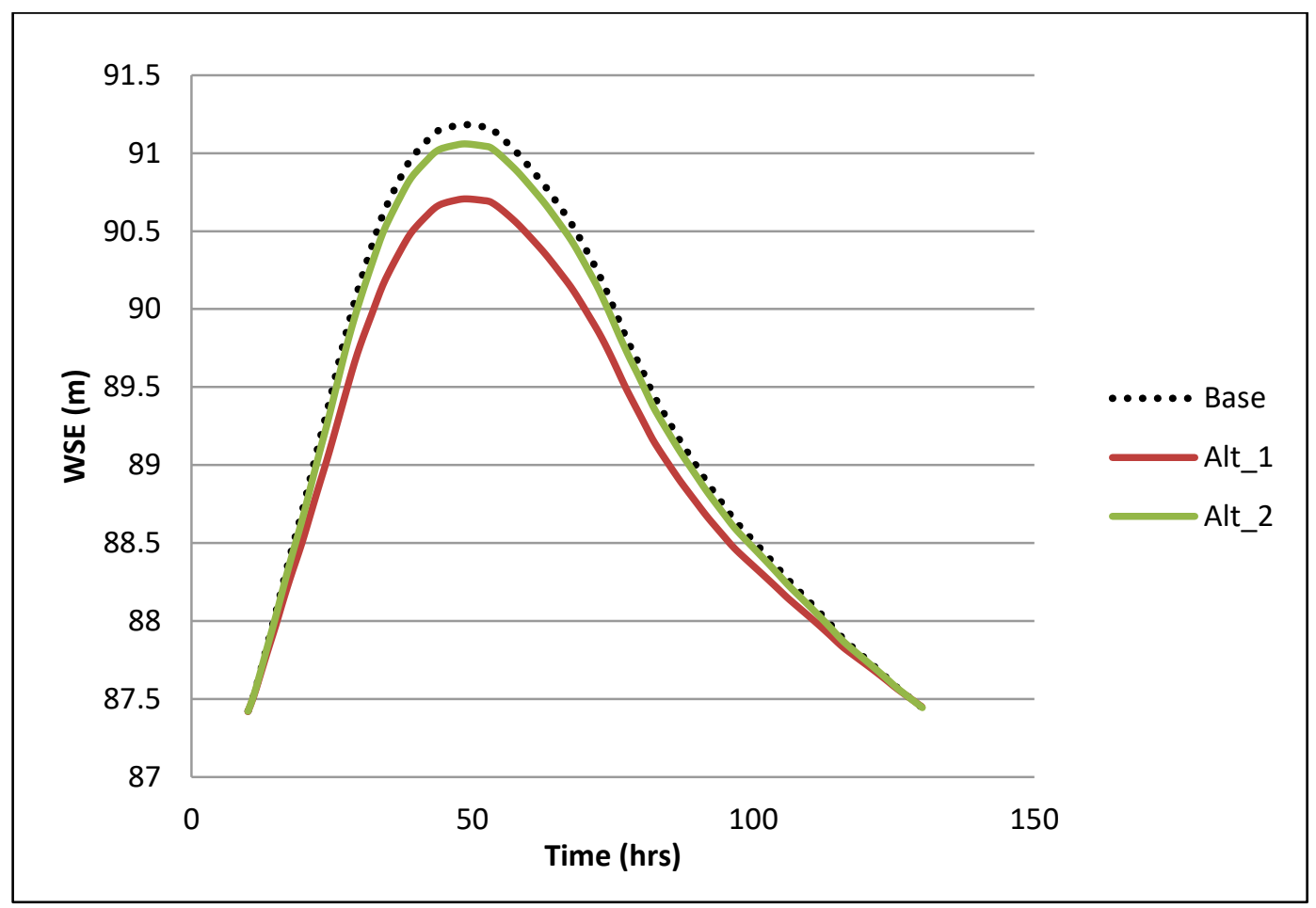

Figure 21 shows the WSE at the observation point at the levee setbacks for the base condition, Alternative 1, and Alternative 2 during the higher flows of the synthetic unit hydrograph with a roughness coefficient of 0.040. The maximum WSE is reduced approximately $0.2 \mathrm{~m}(0.66 \mathrm{ft})$ for Alternative 1 while Alternative 2 shows no reduction.

Figure 22 shows the WSE for the same scenarios as Figure 21 at the observation point downstream of the levee setback, respectively. The WSE of the levee setback alternatives at the observation point downstream are nearly identical as the WSE of the base condition model. 
Figure 21. WSE at observation point at the levee setback Alternatives 1 and 2.

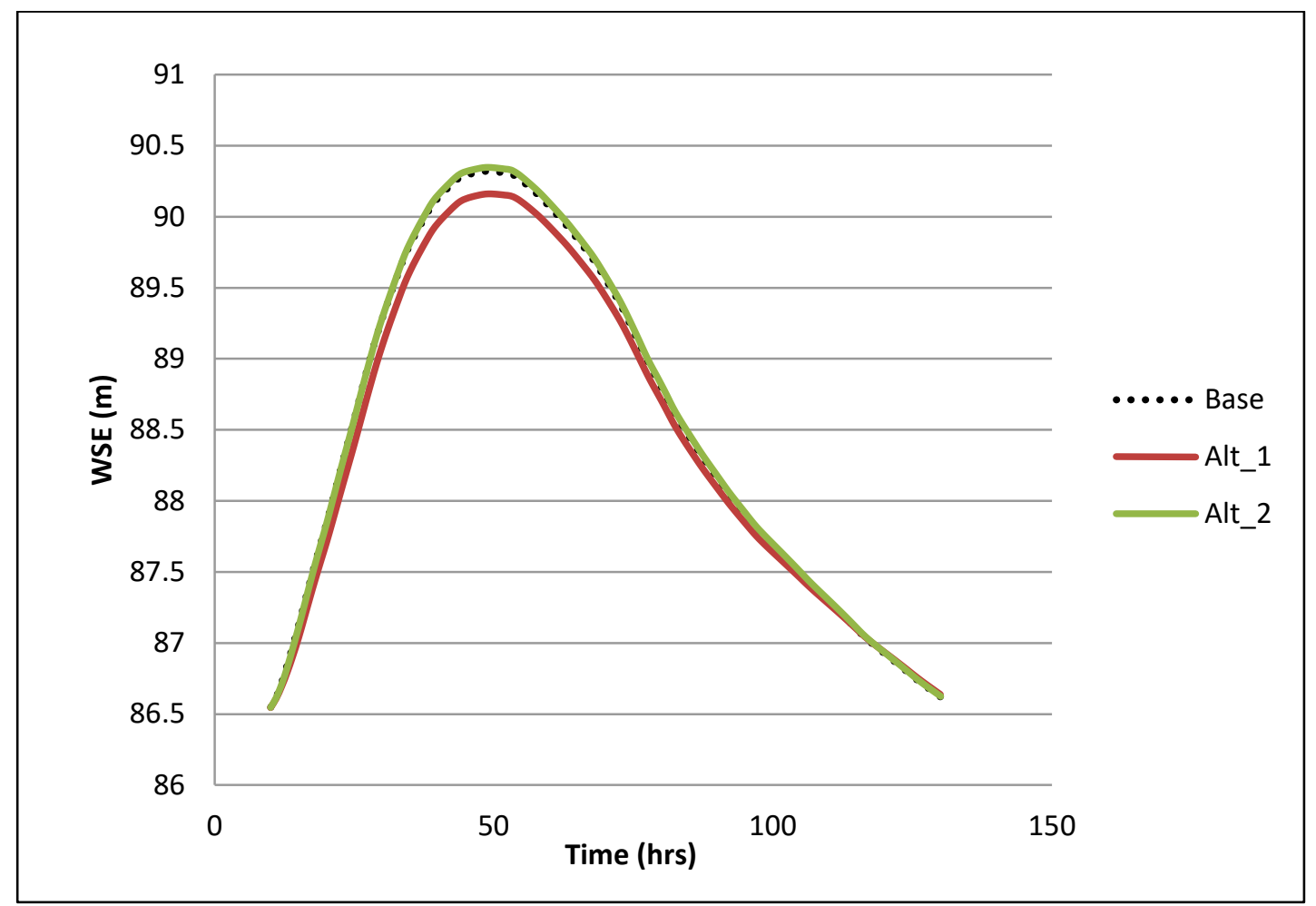

Figure 22. WSE at observation point downstream of the levee setback Alternatives 1 and 2.

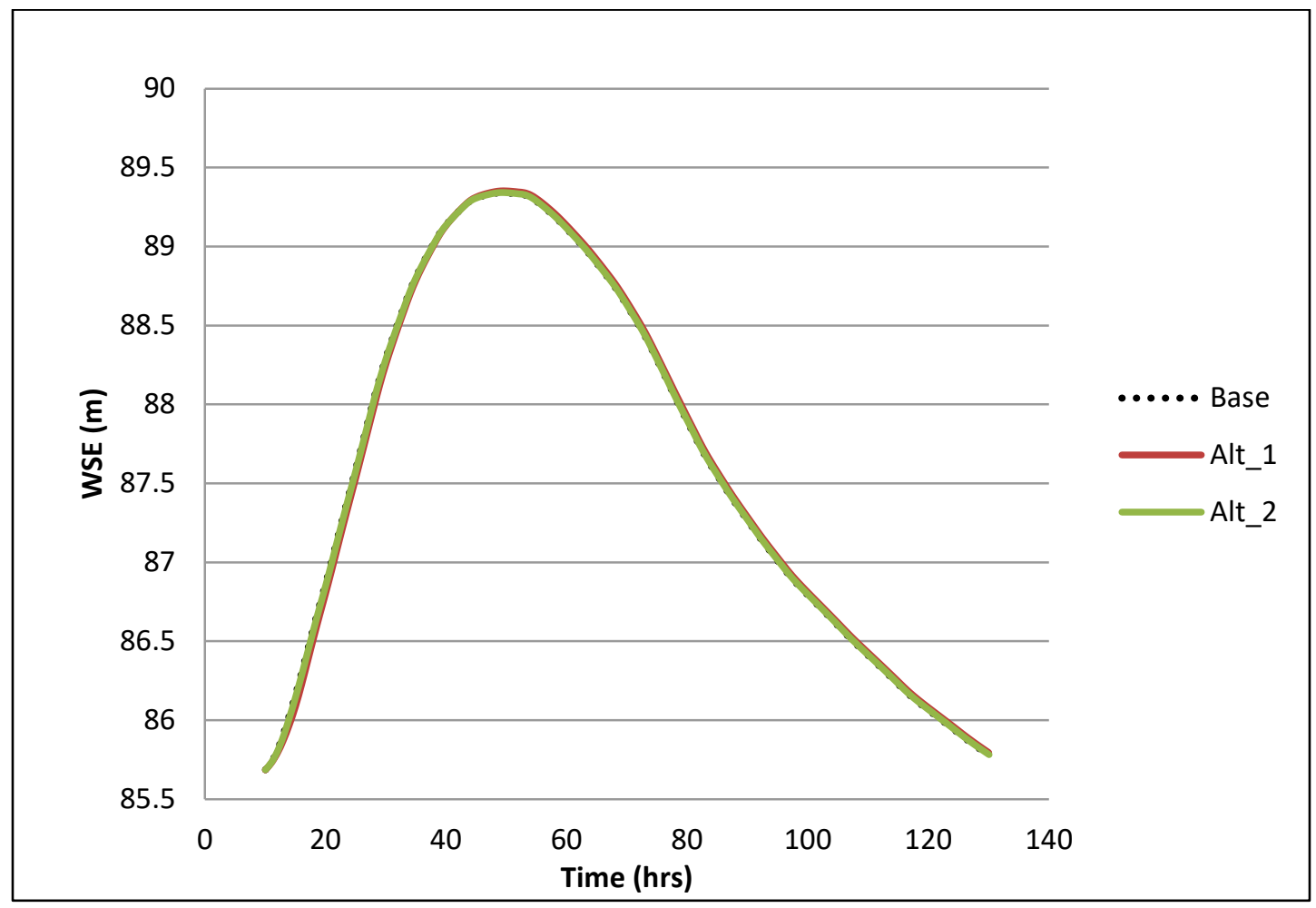


Figure 23 compares the maximum WSE for multiple roughness coefficients at the WSE observation point at the setback for Alternatives 1 and 2. The impact of floodplain roughness on WSE is approximately double that of setback Alternative 1 in these scenarios. Since Alternative 2 has no impact at this WSE observation point, the base condition and Alternative 2 plots are approximately the same.

Figure 23. Maximum WSE at the setback observation point (Alternatives 1 and 2).

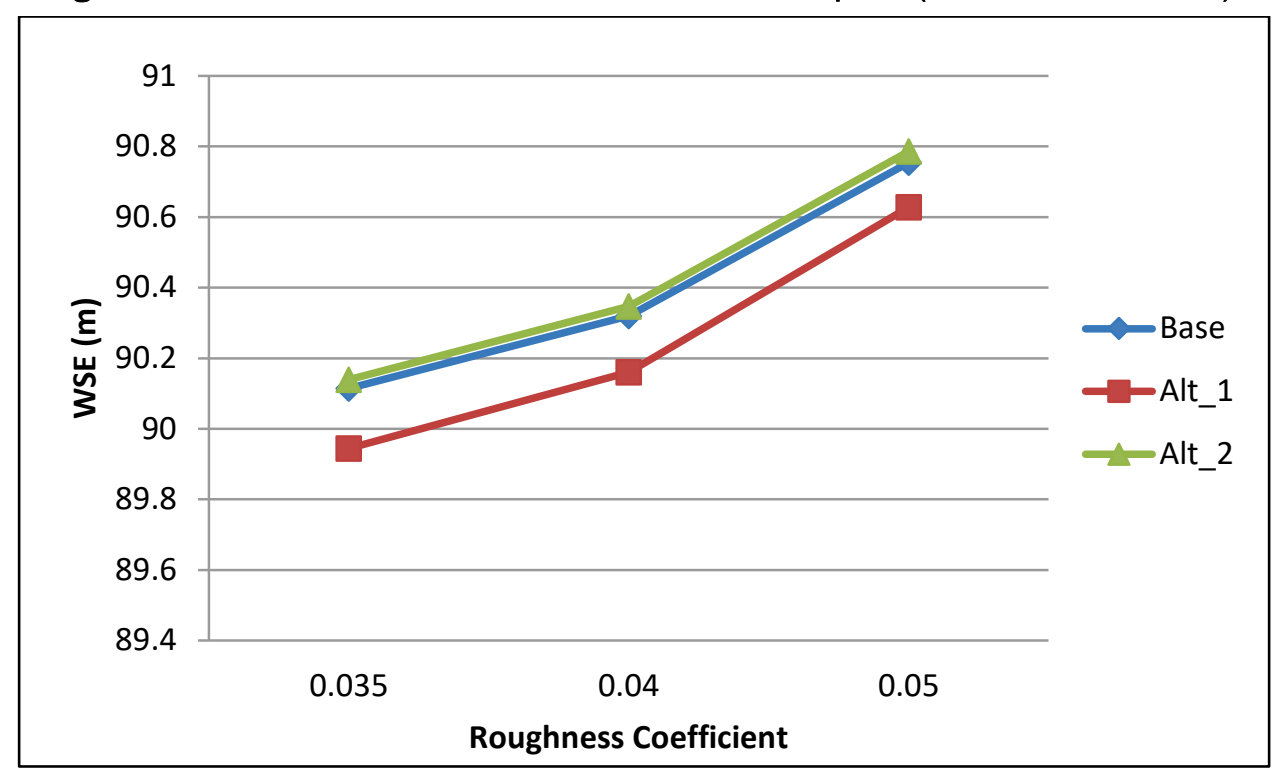

Figure 24 shows the difference in maximum WSE (base condition minus levee setback alternative) for the three WSE observation points of Alternatives 1 and 3, which have the same area but on opposite meanders. The effect of both alternatives on the maximum WSE is very similar. 
Figure 24. Change in maximum WSE (base condition minus levee setback alternative) at WSE observation points for levee setback Alternatives 1 and 3.

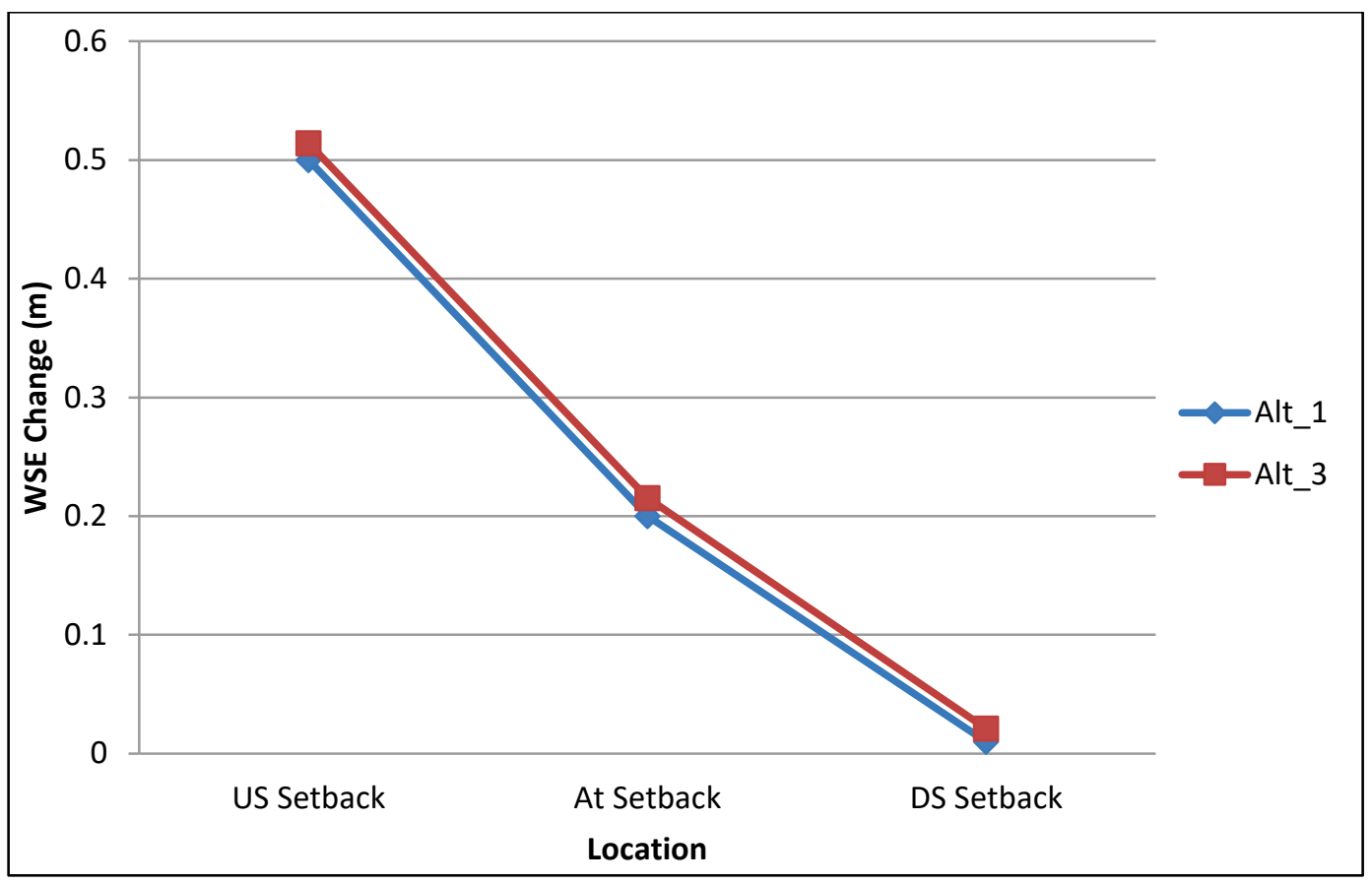

The results of the sinuous channel case indicate that levee setbacks can reduce the WSE for large floods upstream of and at the setback locations. However, there was no observed reduction in the WSE downstream of the levee setback. The largest impact on the WSE occurs upstream of the levee setbacks for both cases: the straight and sinuous channels. The change in the WSE due to the levee setback decreases in the downstream direction.

Figure 25 shows the OV of the base condition model for the peak discharge and an overbank roughness of 0.040 . The maximum velocity in the channel is approximately $2.7 \mathrm{~m} / \mathrm{s}(8.86 \mathrm{ft} / \mathrm{s})$ while the maximum velocities in the overbanks are between 1 and $1.2 \mathrm{~m} / \mathrm{s}(3.28$ and $3.94 \mathrm{ft} / \mathrm{s})$. The maximum velocity in the sinuous channel is slightly slower than the maximum velocity in the straight channel because of the reduced channel slope due to the meanders. 
Figure 25. OV (meters/second) of the sinuous channel initial conditions model during the peak discharge.

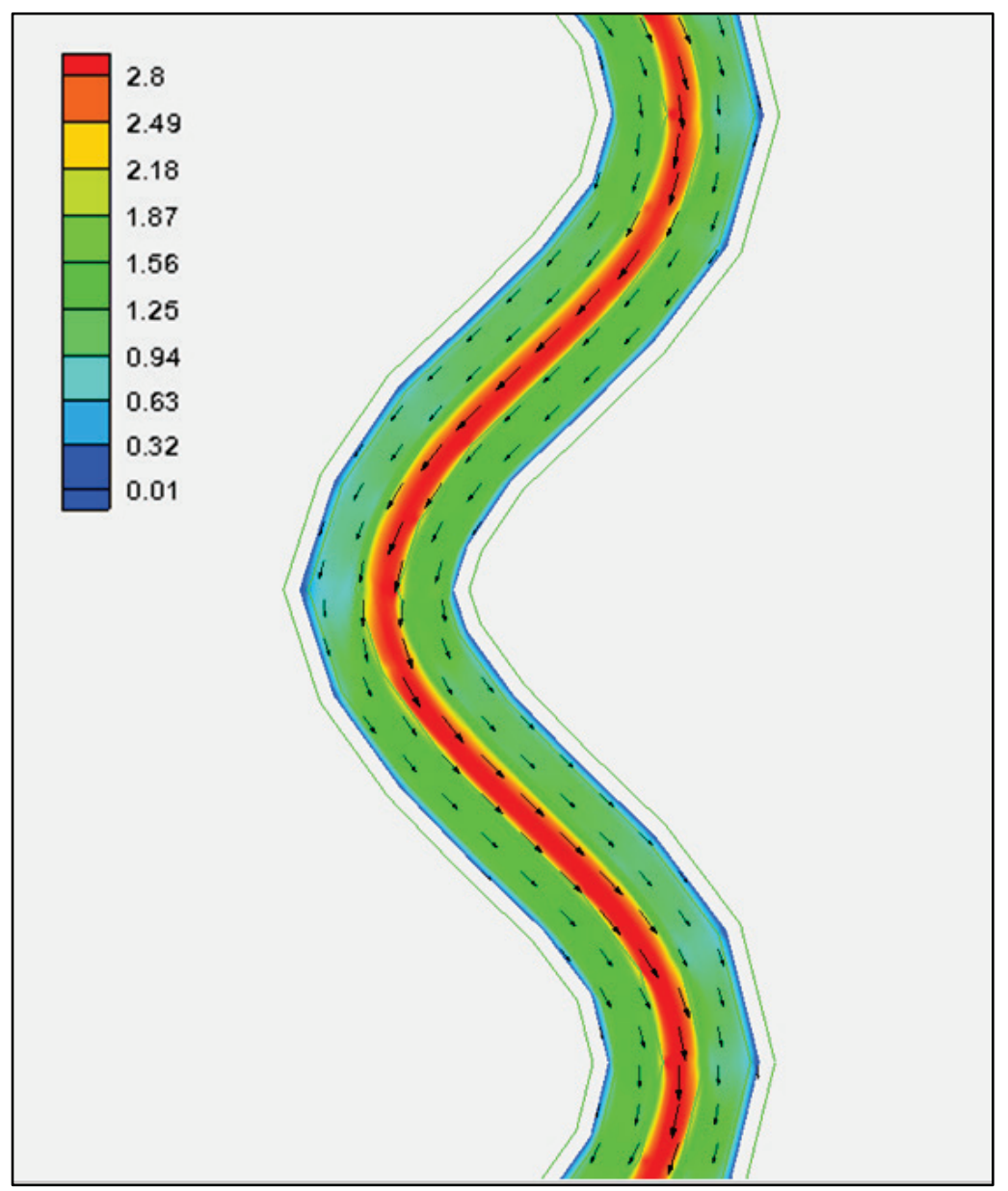

Figure 26 and Figure 27 show the OV of Alternatives 1 and 2, respectively, for the peak discharge and an overbank roughness of 0.040. The OV decreases in the channel and floodplain within the levee setback area for both alternatives when compared with the base condition. The reduction in velocity and WSE along the toe of the levee setbacks will also reduce shear stresses associated with large flows. 
Figure 26. OV (meters/second) of the sinuous channel Alternative 1 during the peak discharge.

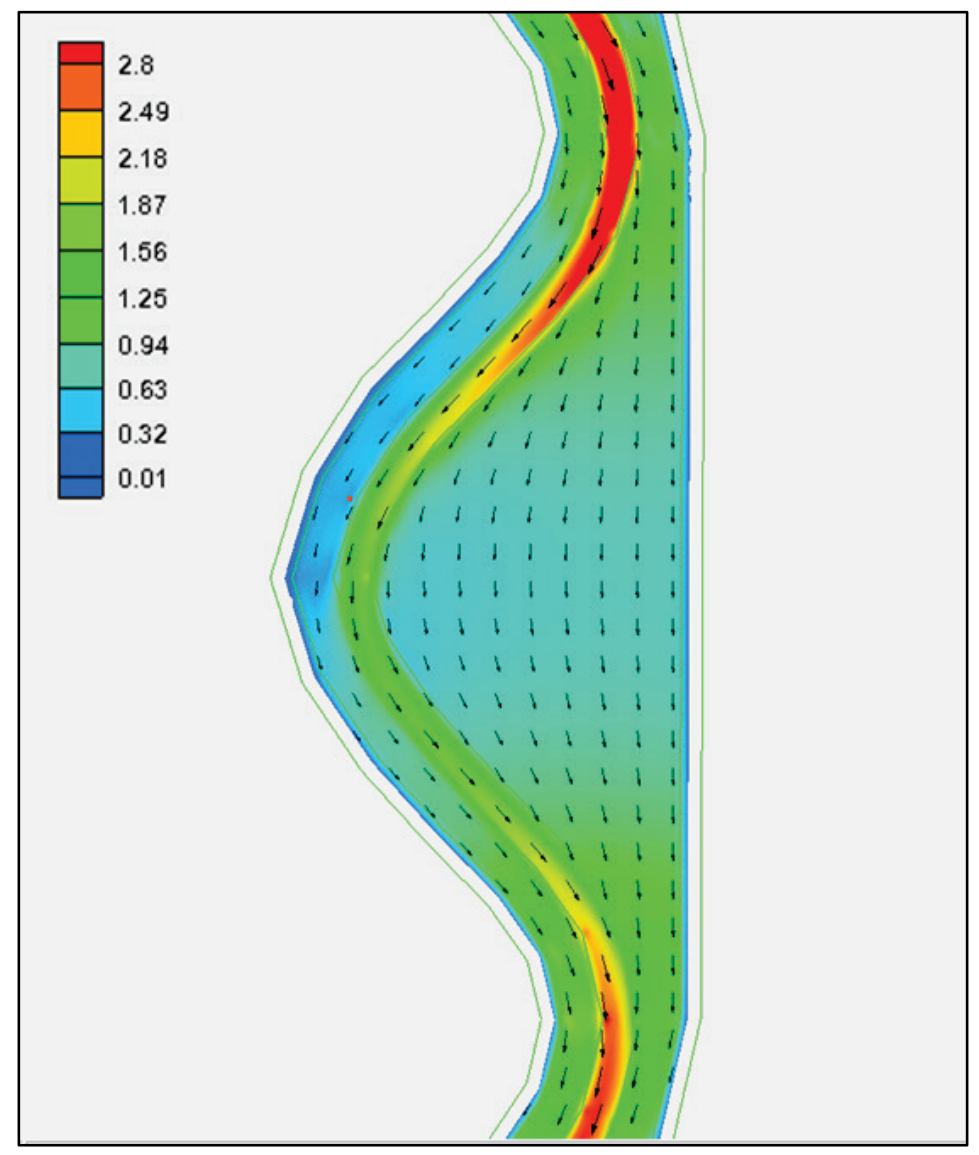

Since the larger impact in the reduction of WSE occurs upstream of the levee setback, the OV increases upstream of the levee setback. The OV at the WSE observation point upstream of the levee setback increases approximately $11 \%$ for Alternative 1 and $3 \%$ for Alternative 2, when compared with the base condition. The increase in OV upstream of the levee setback could increase the risk of scour along the bank and may require additional bank protection beyond that required for a traditional levee.

Figure 28 shows the OV of Alternative 3 for the peak discharge and an overbank roughness coefficient of 0.040. The velocity follows a similar pattern to that seen for Alternative 1. 
Figure 27. OV (meters/second) of the sinuous channel Alternative 2 during the peak discharge.

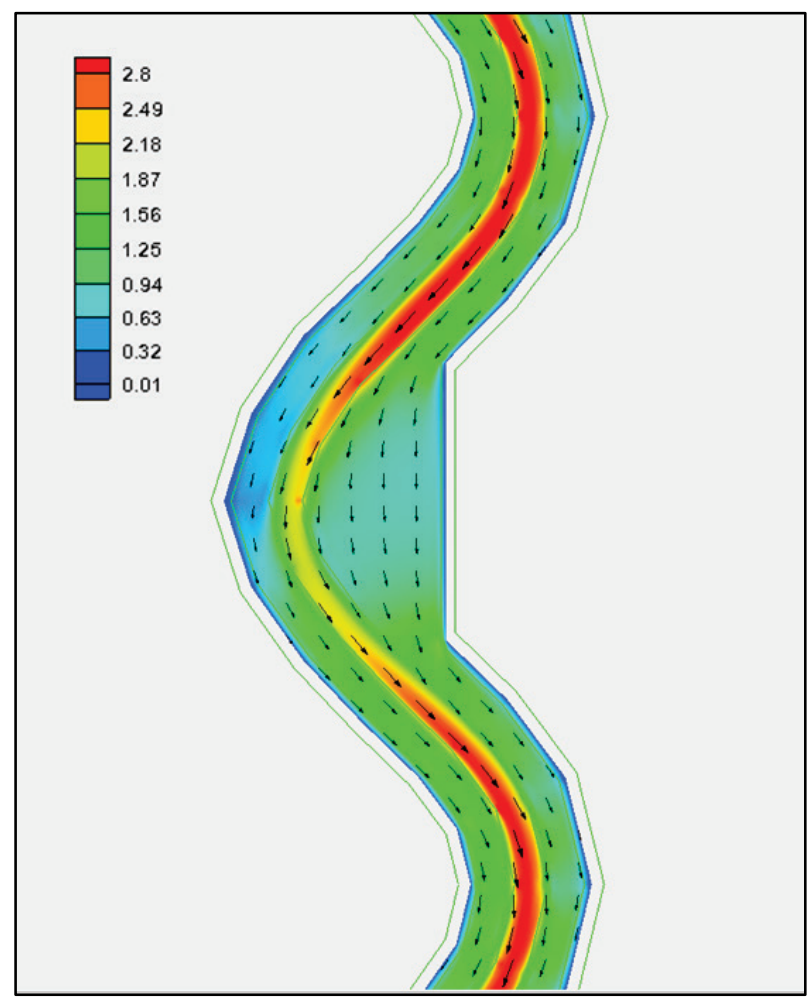

Figure 28. OV (meters/second) of the sinuous channel Alternative 3 during the peak discharge.

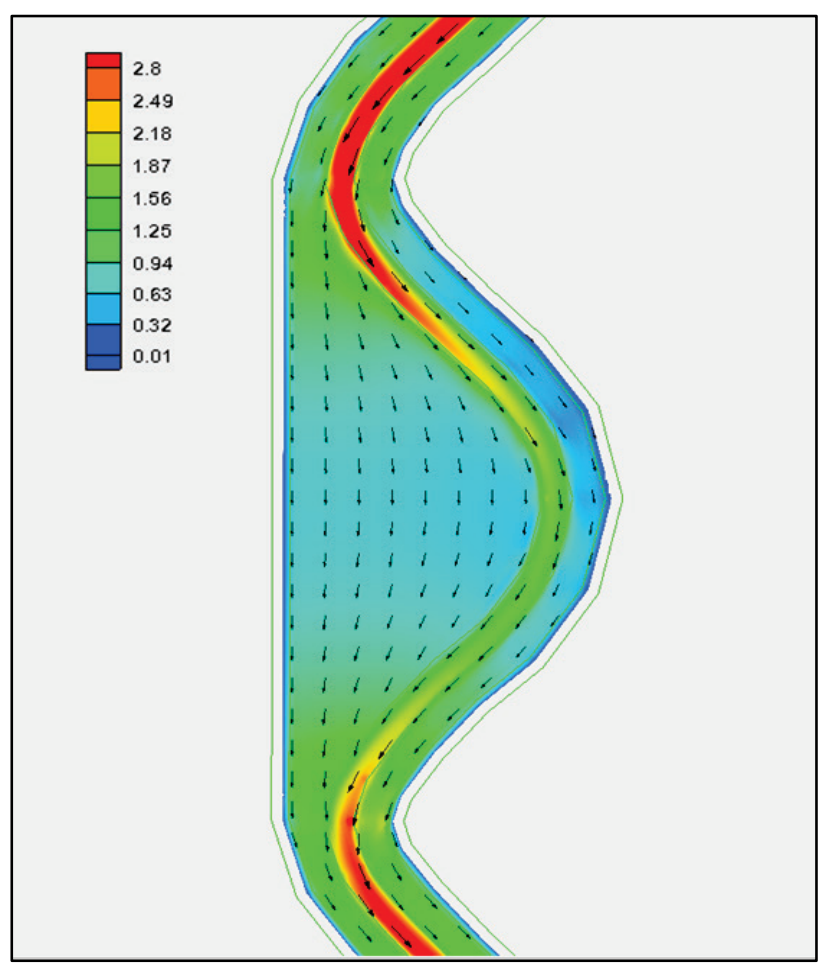




\section{Conclusions}

The straight and sinuous hypothetical levee setback alternatives show a reduction in the water surface elevation (WSE) upstream of and at the levee setback area when compared to the base condition for a large flood event. The reduction in WSE increases in the upstream direction from the levee setback location and decreases in the downstream direction. The WSE impacts likely diminish farther away from the setback, beyond the boundaries of the models used in this study. An additional study is needed to investigate how far upstream a levee setback can reduce WSEs. Overland velocity $(\mathrm{OV})$ is reduced in the channel and the floodplain within the setback area. The reduction in the OV and WSE could potentially reduce shear stress along the toe of the levee within the setback area, reducing the risk of levee failure. Conversely, the results indicate that OV in the channel increases upstream of the levee setback when compared with the base condition. The increase in OV may help to remove sediment from the channel. However, higher velocities may increase the risk of bank erosion. The OV may also increase along the levee setback transitions due to the constriction in the floodplain area.

Since these conclusions are based on hypothetical models, it is recommended that these findings be verified by comparison with an existing levee setback project that has been constructed, comparing the pre-project conditions to the with-project conditions. 


\section{References}

Berger, R. C., J. N. Tate, G. L. Brown, and G. Savant. 2015. Adaptive Hydraulics (AdH) Version 4.5 Hydrodynamic User Manual. Vicksburg, MS: U.S. Army Engineer Research and Development Center. https://chl.erdc.dren.mil/adh/documentation/AdH_Manual_Hydrodynamic-Version4.5.pdf.

Chow, V. T. 1959. Open-Channel Hydraulics. Civil Engineering Series. New York: McGrawHill Higher Education.

Dahl, T. A., C. H. Theiling, and W. Echevarria. 2017. Overview of Levee Setback Projects and Benefits. ERDC/CHL CHETN-VII-17. Vicksburg, MS: U.S. Army Engineer Research and Development Center. http://dx.doi.org/10.21079/11681/22767.

Smith, D. L., S. P. Miner, C. H. Theiling, R. Behm, and J. M. Nestler. 2017. Setback Levees: An Innovative, Cost-Effective, and Sustainable Solution for Improved Flood Management. ERDC/EL SR-17-3. Vicksburg, MS: U.S. Army Engineer Research and Development Center. http://dx.doi.org/10.21079/11681/22736.

Sturm, T. W.2001. Open-Channel Hydraulics. Water Resources and Environmental Series. Boston: McGraw-Hill.

U.S. Army Corps of Engineers Levee Safety Program. 2017. http://www.usace.army.mil/Missions/Civil-Works/Levee-Safety-Program/USACE-ProgramLevees/. 


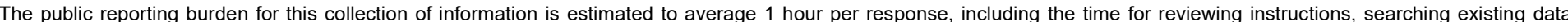

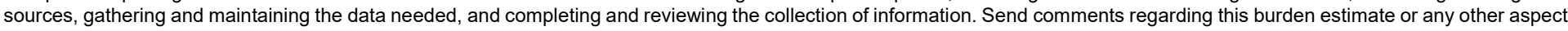

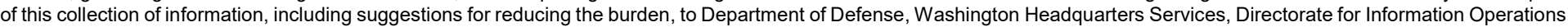

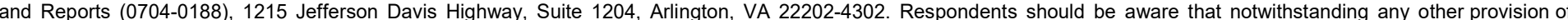
law, no person shall be subject to any penalty for failing to comply with a collection of information if it does not display a currently valid OMB control number. PLEASE DO NOT RETURN YOUR FORM TO THE ABOVE ADDRESS.

\begin{tabular}{l|l}
\hline 1. REPORT DATE & 2. REPORT TYPE \\
January 2018 & Final Report
\end{tabular}

\section{TITLE AND SUBTITLE}

Numerical Hydrodynamic Study of Hypothetical Levee Setback Scenarios

\section{DATES COVERED (From - To)}

5a. CONTRACT NUMBER

5b. GRANT NUMBER

5c. PROGRAM ELEMENT NUMBER

5d. PROJECT NUMBER

454633

5e. TASK NUMBER

5f. WORK UNIT NUMBER

8. PERFORMING ORGANIZATION REPORT NUMBER

ERDC/CHL TR-18-1

10. SPONSOR/MONITOR'S ACRONYM(S)

USACE

11. SPONSOR/MONITOR'S REPORT NUMBER(S)

\section{DISTRIBUTION/AVAILABILITY STATEMENT}

Approved for public release; distribution is unlimited.

\section{SUPPLEMENTARY NOTES}

\section{ABSTRACT}

A numerical hydrodynamic study was conducted to compare multiple levee setback alternatives to the base condition (levee without setbacks). The models developed for this study are hypothetical. An unsteady unit hydrograph representing a flood wave was used to perform the simulations. The levee setback alternatives show a reduction in water surface elevation upstream of and at the setback area when compared with the base condition. The overland water velocity increases upstream of the setback area and decreases at the levee setback area and downstream when compared with the base condition. These hypothetical results indicate that levee setback may be an option to reduce flood risk at a given location; however, exact physical setting and processes, economics, and environmental implications of alternatives must be examined to determine the viability of alternatives. This report provides preliminary information about the effects of levee setbacks on flows and water surface elevations that can be helpful for planners and engineers considering adjusting levee alignment as a flood management alternative.

\section{SUBJECT TERMS}

Flood control, Hydrodynamics, Levees, Levee setbacks, Numerical analysis, Rivers--Regulation

\section{SECURITY CLASSIFICATION OF:}

\begin{tabular}{|l|l|l|}
\hline a. REPORT & b. ABSTRACT & c. THIS PAGE \\
Unclassified & Unclassified & Unclassified \\
& &
\end{tabular}

17. LIMITATION OF
ABSTRACT
SAR

18. NUMBER OF PAGES

35 19a. NAME OF RESPONSIBLE PERSON Travis Dahl

19b. TELEPHONE NUMBER (Include area code) 601-634-2371 